\title{
Complementary Spiritist Therapy: Systematic Review of Scientific Evidence
}

\author{
Giancarlo Lucchetti, ${ }^{1}$ Alessandra L. Granero Lucchetti, ${ }^{1}$ Rodrigo M. Bassi, ${ }^{1}$ \\ and Marlene Rossi Severino Nobre ${ }^{2}$ \\ ${ }^{1}$ Research Department, São Paulo Medical Spiritist Association, Avenida Juriti 367 SP Apto 131, 04520-000 São Paulo, SP, Brazil
${ }^{2}$ Research Department, Brazilian and International Medical Spiritist Associations, Rua Pedro Severino, $323-1^{\circ}$ Andar,
04310-060 São Paulo, SP, Brazil
}

Correspondence should be addressed to Giancarlo Lucchetti, g.lucchetti@yahoo.com.br

Received 24 June 2010; Revised 1 February 2011; Accepted 27 February 2011

Copyright (C) 2011 Giancarlo Lucchetti et al. This is an open access article distributed under the Creative Commons Attribution License, which permits unrestricted use, distribution, and reproduction in any medium, provided the original work is properly cited.

\begin{abstract}
Spiritism is the third most common religion in Brazil, and its therapies have been used by millions worldwide. These therapies are based on therapeutic resources including prayer, laying on of hands, fluidotherapy (magnetized water), charity/volunteering, spirit education/moral values, and disobsession (spirit release therapy). This paper presents a systematic review of the current literature on the relationship among health outcomes and 6 predictors: prayer, laying on of hands, magnetized/fluidic water, charity/volunteering, spirit education (virtuous life and positive affect), and spirit release therapy. All articles were analyzed according to inclusion/exclusion criteria, Newcastle-Ottawa and Jadad score. At present, there is moderate to strong evidence that volunteering and positive affect are linked to better health outcomes. Furthermore, laying on of hands, virtuous life, and praying for oneself also seem to be associated to positive findings. Nevertheless, there is a lack of studies on magnetized water and spirit release therapy. In summary, science is indirectly demonstrating that some of these therapies can be associated to better health outcomes and that other therapies have been overlooked or poorly investigated. Further studies in this field could contribute to the disciplines of Complementary and Alternative Medicine by investigating the relationship between body, mind, and soul/spirit.
\end{abstract}

\section{Introduction}

According to the latest Brazilian Demographic Census [1], "Spiritism" is the third largest religion in Brazil with approximately 2.3 million followers. Its believers make up the most well-educated (60\% have at least 11 years of education) and wealthy populations in Brazil.

Spiritism was founded by the French teacher and educator Hippolyte Léon Denizard Rivail also known by his pseudonym Allan Kardec [2]. From the outset, Rivail became interested in the wildly popular phenomenon of spirit tapping and decided to carry out his own research. $\mathrm{He}$ compiled a list of questions and began working with mediums and channelers to put them to spirits.

In 1857, he published his first book on Spiritism entitled, "The Spirits' Book" [3], comprising a series of 1019 questions exploring matters concerning, for example, the nature of spirits. During his life, Rivail always strove to link experimental science with religion [4] and defined Spiritism as "a science which deals with the nature, origin and destiny of Spirits, as well as their relationship with the corporeal World" [5].

Since its emergence Kardec tried to use rigorous methods, such as those reported in Revue Spirite [6], "To this end, we gather facts, examine them, scrutinize them in painstaking detail, comment on them, discuss them objectively, without over-enthusiasm, and this was how we came to discover the admirable links among all elements of this vast science which address the most serious issues of humanity."

Furthermore, Kardec stated [7], "Spiritism proceeds in the same way as the positive sciences, by using the experimental method. When facts of a new kind are observed, facts that cannot be explained by known laws, it observes, compares and analyzes them. Reasoning then from the effects to the causes, it discovers the laws which govern them."

Another example of the scientific aspect of Spiritism can be noted in "The Genesis" $[8,9]$, "science without Spiritism 
finds itself utterly powerless to explain certain phenomena by laws of matter alone; - while Spiritism without science would lack support and control."

Spiritism adopts a dualistic concept of the human being. It postulates that we are, essentially, immortal spirits that temporarily inhabit physical bodies for several necessary incarnations to attain moral and intellectual improvement. It also implies a possible beneficent or maleficent influence of the spirits over the incarnate human. In the case of maleficent influence, it is called "obsession" and it could be the cause of mental imbalance or cases of "madness" [10].

With the Spiritist Doctrine emerged the Complementary Spiritist Therapy [11], based on a range of therapeutic resources including prayer, laying on of hands, fluidotherapy (fluidic water or magnetized water), charity, spirit education, and disobsession (spirit release therapy). The name "Complementary" derives from the fact that Spiritist Therapy is used in conjunction with conventional medicine and not in place of it [12].

According to recent studies [13], there are more than 1650 Spiritist centers and numerous Spiritist hospitals throughout Brazil. Furthermore, practitioners of other religions (such as Catholics, Protestants, Jews, and others) make use of the Spiritist centers for spiritual treatment in order to cure or relieve their symptoms. In view of the numbers of people attending these centers, allied with the current expansion of their popularity, and the fact that some centers have been developing their protocols for more than 131 years, it is fair to assume that the protocols used have enjoyed considerable success. The Federation for Spiritism in Sao Paulo, Brazil serves between 7000 and 10000 people daily. Most of these people come to attend classes and/or receive spiritual healing. All Spiritist treatments are provided free of charge.

There are also thousands of these centers in Spanishspeaking countries in Latin America and more than 161 centers in 31 countries outside Latin America, including more than 70 in the United States [13].

However, few studies, if any, have evaluated the efficacy of the healing practices of Spiritist centers in randomized double-blind controlled trials.

The aim of this paper was to examine the scientific basis for some Spiritist therapies in terms of health outcomes. This was a systematic review which focused on those studies that provided the most robust methodologies and thus presented the lowest likelihood of bias and confounding. Hypotheses supported by strong and consistent evidence have been highlighted, and gaps in the literature representing opportunities for future research were also identified.

We identified six hypotheses that underlie most of the recommended Spiritist therapies, based on the Spiritist literature available. These hypotheses were as follows (1) prayer for oneself is associated with better health outcomes; (2) laying on of hands is associated with better health outcomes; (3) magnetized water is associated with better health outcomes; (4) volunteerism is associated to better health outcomes; (5) virtuous life and positive affect are associated with better health outcomes; (6) spirit release therapy is associated with better health outcomes.

\section{Methods}

2.1. Search Strategy. We carried out a search of published studies, without language restriction, using the Medline database (January, 1966, to March, 2010). Keywords used (Table 1) for each hypothesis were as follows: (1) prayer for oneself: "Prayer," "Pray," "Religious Meditation"; (2) laying on of hands: "Laying on of hands," "Imposition of hands," "Therapeutic touch," "Reiki," "Johrei"; (3) fluidotherapy: "fluidic water," "Magnetized water," "Water healing," "Water heal," "Energized water"; (4) charity: "Volunteering," "Helping others"; (5) spirit education (Virtuous life and Positive affect): "Moral values," "positive affect," "anger proneness," "Resilience" and "prospective," "positive emotions," "Emotional style," "Goodness not Goodnessof-fit," "Benevolence," "Humility," "Virtues," "Peacefulness," "Kindness"; (6) disobsession (spirit release therapy): "Possession Trance," "Spirit Release therapy," "Spirit possession," "spiritist healers," "spiritist healing," "spiritual surgery," "spiritist," "spiritists." We decided to limit the searches with the function [title] which retrieves only articles whose titles contain these specific words.

Citations were also screened and full reports of potentially relevant studies obtained. We applied inclusion and exclusion criteria and assessed methodological criteria.

2.2. Study Exclusion Criteria. In line with a previous article based on systematic reviews on spirituality/religiosity [14], studies were categorized as inconclusive and subsequently eliminated from further consideration if their designs made it impossible to rule out bias, confounding, or chance as alternative explanations for results. Specific exclusions were made for any of the following criteria.

(i) No attempt to control for any potential confounder: studies that reported a univariate association with no attempt to control for such basic confounders as age, gender, or ethnicity were eliminated.

(ii) Cross-sectional design: cross-sectional studies are unable to determine the temporal sequence of events.

(iii) No statistical analyses: studies that failed to conduct statistical analyses did not assess the role of chance in accounting for the observed association.

(iv) Earlier reports on the same cohort: series of reports are often conducted on a specific therapy-health link covering the same cohort differing only in terms of length of followup.

(v) No evaluation of health outcomes: some studies report only findings related to the opinions of health care professionals on a given issue.

(vi) Review or theoretical studies: studies that proposed theories or hypothesis were excluded, as were narrative reviews.

(vii) Experimental studies: explaining the mechanisms by which some therapies work. 
TABLe 1: Data abstraction.

\begin{tabular}{|c|c|c|c|c|c|c|c|}
\hline $\begin{array}{l}\text { Keywords used (only articles with } \\
\text { these words in the title were included) }\end{array}$ & $\begin{array}{l}\text { Articles } \\
\text { found }\end{array}$ & $\begin{array}{l}\text { Excluded in } \\
\text { Phase } 1\end{array}$ & Phase 2 & $\begin{array}{l}\text { Excluded in } \\
\text { Phase } 2\end{array}$ & Phase 3 & $\begin{array}{l}\text { Excluded in } \\
\text { Phase } 3\end{array}$ & $\begin{array}{l}\text { Articles included for } \\
\text { the final analysis }\end{array}$ \\
\hline \multicolumn{8}{|l|}{ Prayer } \\
\hline Prayer & 428 & 384 & 44 & 33 & 11 & 5 & 6 \\
\hline Pray & 39 & 38 & 1 & 1 & 0 & 0 & 0 \\
\hline Religious Meditation & 0 & 0 & 0 & 0 & 0 & 0 & 0 \\
\hline \multicolumn{8}{|l|}{ Laying on of hands } \\
\hline Laying on of hands & 18 & 17 & 1 & 0 & 1 & 1 & 0 \\
\hline Imposition of hands & 0 & 0 & 0 & 0 & 0 & 0 & 0 \\
\hline Therapeutic touch & 261 & 220 & 41 & 12 & 29 & 18 & 11 \\
\hline Reiki & 0 & 0 & 0 & 0 & 0 & 0 & 0 \\
\hline Johrei & 9 & 1 & 8 & 3 & 5 & 5 & 0 \\
\hline \multicolumn{8}{|l|}{ Fluidotherapy } \\
\hline Fluidic water & 0 & 0 & 0 & 0 & 0 & 0 & 0 \\
\hline Magnetized water & 7 & 1 & 6 & 5 & 1 & 0 & 1 \\
\hline Magnetic water & 9 & 7 & 2 & 1 & 1 & 0 & 1 \\
\hline Water Healing & 0 & 0 & 0 & 0 & 0 & 0 & 0 \\
\hline Water Heal & 0 & 0 & 0 & 0 & 0 & 0 & 0 \\
\hline Energized Water & 0 & 0 & 0 & 0 & 0 & 0 & 0 \\
\hline \multicolumn{8}{|l|}{ Charity } \\
\hline Volunteering & 242 & 216 & 26 & 14 & 12 & 2 & 10 \\
\hline Helping others & 41 & 40 & 1 & 1 & 0 & 0 & 0 \\
\hline \multicolumn{8}{|l|}{ Spirit education } \\
\hline Moral values & 59 & 57 & 2 & 2 & 0 & 0 & 0 \\
\hline Anger proneness & 5 & 3 & 2 & 0 & 2 & 0 & 2 \\
\hline Resilience and prospective & 97 & 79 & 18 & 13 & 5 & 2 & 3 \\
\hline Positive Emotions & 53 & 41 & 12 & 5 & 7 & 5 & 2 \\
\hline Positive affect & 142 & 110 & 32 & 12 & 20 & 11 & 9 \\
\hline Emotional style & 4 & 1 & 3 & 0 & 3 & 3 & 0 \\
\hline Goodness NOT, Goodness-of-fit & 82 & 82 & 0 & 0 & 0 & 0 & 0 \\
\hline Benevolence & 49 & 48 & 1 & 0 & 1 & 0 & 1 \\
\hline Humility & 129 & 128 & 1 & 1 & 0 & 0 & 0 \\
\hline Virtues & 215 & 214 & 1 & 1 & 0 & 0 & 0 \\
\hline Peacefulness & 1 & 1 & 0 & 0 & 0 & 0 & 0 \\
\hline Kindness & 125 & 119 & 6 & 0 & 6 & 2 & 4 \\
\hline \multicolumn{8}{|l|}{ Disobsession } \\
\hline Possession Trance & 3 & 1 & 20 & 19 & 1 & 1 & 0 \\
\hline Spirit Release Therapy & 0 & 0 & 0 & 0 & 0 & 0 & 0 \\
\hline Spirit Possession & 34 & 28 & 6 & 5 & 1 & 1 & 0 \\
\hline Spiritist Healers & 0 & 0 & 0 & 0 & 0 & 0 & 0 \\
\hline Spiritist Healing & 2 & 0 & 2 & 1 & 1 & 1 & 0 \\
\hline Spiritual surgery & 0 & 0 & 0 & 0 & 0 & 0 & 0 \\
\hline Spiritist & 8 & 4 & 4 & 3 & 1 & 1 & 0 \\
\hline Spiritists & 2 & 1 & 1 & 0 & 1 & 1 & 0 \\
\hline Total & 1998 & 1752 & 246 & 138 & 109 & 59 & 50 \\
\hline
\end{tabular}


2.3. Criteria for the Evaluation of Included Studies. Besides number of patients, studies were categorized as case-control or cohort, and if cohort, they were either prospective or retrospective. Prospective cohort studies were defined as those that identified a group of participants and followed them over time, whereas retrospective cohort studies were defined as those that identified a group of participants and used existing records to evaluate their clinical characteristics and course. The Newcastle-Ottawa scale [15] was used to assess the quality of each study (cutoff $>6$ adopted [16]). This measure assesses the methodology aspects of observational studies and encompasses the variables study quality, including selection of cases, comparability of populations, and ascertainment of exposure to risks. In all cases, disagreements among raters were resolved through discussion to reach a final consensus.

Clinical trials were rated using the Jadad score [17]. This score is based on a scoring system to assess the methodological quality of clinical trials. Essentially it evaluates randomisation, blinding, and the mention of dropouts. Trials are scored on a scale of one to five, with higher scores implying higher quality. We decided to exclude all papers on the topic with a Jadad score of 3 or less.

2.4. Outcomes of Interest and Definitions. Health outcome was defined in the present study as "a change (or lack of change) in health status caused by a therapy or factor compared with a previously documented health status using disease-specific measures, general quality of life measures or utility measures."

The following outcomes were used to compare the users and nonusers of some principles of Spiritist therapy, based on the literature available after article selection.

(a) Prayer for oneself: hospitalization, complications after coronary artery bypass graft surgery (CABG), quality of life, stress, depressive symptoms, optimism, and general distress.

(b) Laying on of hands: behavioral symptoms, fatigue, pain, anxiety, satisfaction with life, and functional status.

(c) Fluidotherapy (magnetized water): dental calculus (this was the only health outcome evaluated by good methodological studies).

(d) Charity/volunteering: physical activity, self-reported health, depression, mortality, well-being, functional disability and life satisfaction.

(e) Positive affect and virtuous life: cardiovascular outcomes (peripheral artery disease, coronary heart disease), mortality, frailty, self-reported health status, functional status, remission from personality disorders, distress, HbA1c levels, well-being, satisfaction with life, happiness, pain, anger and psychological distress, and social connection.

(f) Disobsession (spirit release therapy): no studies were included in the final analysis regarding this issue.

\subsection{Data Abstraction}

Data Abstraction Consisted of 3 Phases.

Phase 1. Two researchers (GL, ALGL) independently screened the list of references (full articles were retrieved for further analysis whenever necessary) to exclude reports not assessing the issue in-hand, not assessing the relationship between different types of therapies and health outcomes, as well as articles not containing abstracts.

Phase 2. Each study was characterized according to: year of publication; country of origin and population evaluated; length of followup; number, agem and gender of the participants, and health outcome. All articles not fulfilling the inclusion criteria and which met the exclusion criteria were omitted from the final analysis.

Phase 3. Another extensive revision of inclusion and exclusion criteria were performed, and the quality of each study was assessed by the Jadad score for clinical trials and the Newcastle-Ottawa scale for cohort studies. Two researchers (GL and ALGL) rated the articles. The disagreements between the reviewers were discussed with a third reviewer (RMB) and resolved by consensus.

2.6. Statistical Analysis. This paper uses the term systematic review to denote the entire process of retrieving, selecting, appraising, summarizing and reporting evidence, and performing the meta-analysis for the specific statistical technique of combining the data from individual studies.

Due to the nature of this systematic review (the studies are dissimilar with respect to population, outcome, and intervention), no meta-analysis could be performed. Instead, we opted to present those articles supporting each intervention or otherwise, along with the quality of these studies.

\section{Results}

We identified 1998 articles in the preliminary analysis (Table 1). Following the first phase, 1752 were excluded for not assessing the topic analyzed or investigating the association between the therapy and health outcome. Of the 246 articles remaining in Phase 2, 138 were excluded (most studies did not evaluate outcomes, had sample problems, or dealt with intercessory prayer), giving 109 articles.

Finally, further 59 articles were excluded in Phase 3, giving a total of 45 for the final analysis (6 for prayer, 11 for laying on of hands, 2 for fluidic/magnetized water, 10 for charity/volunteering, 21 for spirit education (virtuous life and positive affect), and 0 for disobsession).

Out of the 11 articles regarding prayer for oneself in phase 3 , only 6 were included for final analysis (with the exclusion of 2 articles with Newcastle-Otawa scale $<7 ; 1$ cross-sectional; 1 recorded prayer and 1 experimental study).

Of the 35 studies regarding laying on of hands in Phase 3, 11 were included for final analysis (with the exclusion of 6 noncontrolled trials, 11 with nonmimic therapeutic touch control, and 7 experimental studies). The 2 studies on fluidic/magnetized water in phase 3 were included. 
TABle 2: Hypothesis 1: Private Prayer is associated with better health outcomes.

\begin{tabular}{|c|c|c|c|c|c|c|}
\hline Study & Sample & $\begin{array}{l}\text { Cohort } \\
\text { followup }\end{array}$ & Predictor & Outcome & Results & $\begin{array}{l}\text { Newcastle- } \\
\text { Otawa } \\
\text { grade }\end{array}$ \\
\hline Ai et al. [25] & $\begin{array}{l}177 \text { patients } \\
\text { undergoing } \\
\text { CABG }\end{array}$ & \pm 3 weeks & $\begin{array}{l}\text { Prayer } \\
\text { frequencies }\end{array}$ & $\begin{array}{l}\text { Postoperative } \\
\text { complications } \\
\text { and } \\
\text { hospitalization }\end{array}$ & $\begin{array}{l}\text { Prayer frequencies were associated with } \\
\text { reduced complications but not } \\
\text { hospitalization }\end{array}$ & 8 \\
\hline Ai et al. [25] & $\begin{array}{l}294 \text { patients } \\
\text { following } \\
\text { open-heart } \\
\text { surgery }\end{array}$ & $\pm 4-5$ weeks & Private prayer & Quality of life & $\begin{array}{l}\text { Indirect influence of using prayer for } \\
\text { coping on quality of life through the } \\
\text { mediation of cognitive coping and } \\
\text { perceived social support }\end{array}$ & 8 \\
\hline Ai et al. [27] & $\begin{array}{l}310 \text { patients } \\
\text { following } \\
\text { open-heart } \\
\text { surgery }\end{array}$ & $\pm 4-5$ weeks & Prayer coping & $\begin{array}{l}\text { Preoperative } \\
\text { stress } \\
\text { symptoms }\end{array}$ & $\begin{array}{l}\text { Prayer coping was inversely related to } \\
\text { preoperative stress symptoms }\end{array}$ & 7 \\
\hline $\begin{array}{l}\text { Braam et al. } \\
{[30]}\end{array}$ & $\begin{array}{l}2 \text { assessment } \\
\text { cycles: } \\
\begin{array}{l}N=1,702 \text { and } \\
N=1,346\end{array}\end{array}$ & 3 years & $\begin{array}{l}\text { Prayer } \\
\text { frequencies }\end{array}$ & $\begin{array}{l}\text { Change in } \\
\text { depressive } \\
\text { symptoms }\end{array}$ & $\begin{array}{l}\text { At three-year followup, prayer did not } \\
\text { predict change of depressive symptoms }\end{array}$ & 7 \\
\hline Ai et al. [26] & $\begin{array}{l}246 \text { patients } \\
\text { awaiting cardiac } \\
\text { surgery }\end{array}$ & 2 weeks & $\begin{array}{l}\text { Belief in the } \\
\text { importance of } \\
\text { private prayer }\end{array}$ & Optimism & $\begin{array}{l}\text { Private prayer predicted optimism, along } \\
\text { with older age, better socioeconomic } \\
\text { resources, and healthier affect }\end{array}$ & 7 \\
\hline Ai et al. [28] & $\begin{array}{l}151 \text { older } \\
\text { patients } \\
\text { following CABG }\end{array}$ & 1 year & $\begin{array}{l}\text { Pray about their } \\
\text { postoperative } \\
\text { problems and } \\
\text { private prayer }\end{array}$ & $\begin{array}{l}\text { Depression } \\
\text { and general } \\
\text { distress }\end{array}$ & $\begin{array}{l}\text { Most patients pray about their } \\
\text { postoperative problems and that private } \\
\text { prayer appears to significantly decrease } \\
\text { depression and general distress one year } \\
\text { post-CABG }\end{array}$ & 8 \\
\hline
\end{tabular}

CABG: coronary artery bypass graft surgery.

Of the 12 studies on volunteering in Phase 3, 10 were included for final analysis (2 cross-sectional studies were excluded in this phase), and of the 37 studies assessing spirit education (virtuous life and positive affect), 21 were included (with the exclusion of 7 with Newcastle-Ottawa $<7 ; 2$ not evaluating health outcomes; 7 experimental; 5 positive affect as mediator, not predictor) and 2 with Jadad score less than 4 (from loving-kindness meditation).

The scientific basis for each Spiritist therapy affecting different health outcomes is outlined below.

\section{Prayer for Oneself}

Hypothesis 1. Prayer for oneself is associated with better health outcomes.

Background. The first resource is to pray. The National Center for Complementary and Alternative Medicine in the United States has defined prayer as an active process of communicating with and appealing to a higher spiritual power. According to Amellin [18], 82\% of Americans believe that prayer can cure serious illness, $73 \%$ believe that praying for others can cure illness, and 64\% want their physicians to pray with them. Along the same lines, McCraffey et al. [19] showed that $69 \%$ of those praying for specific medical conditions found prayer very helpful.
Spiritist View. According to Spiritism [20, 21], "It is through prayer that Man obtains the assistance of the good Spirits who come running to sustain him in his good resolutions and inspire wholesome ideas.... By these means he can also turn away from himself all the evil which he attracts through his faults." Furthermore, "Through prayer, the donor casts out from their own midst, the shadows which gather in their daily striving, whilst absorbing renovating substances for their own well-being from the spiritual plane" $[22,23]$.

Scientific Evidence. Six studies scored more than 6 points on the Newcastle-Ottawa scale and were included in the final model (Table 2). All studies evaluated prayer for oneself. We decided not to include some studies on intercessory prayer given its major and intractable methodological flaw, namely, that receipt of prayer cannot be controlled and therefore it is impossible to ascertain to what degree individuals in the control groups were actually the recipients of the "intervention" from loved ones, family members, clergy, or others, besides the research intercessors. For further reading, consult the recommended literature [24].

Examining the studies selected, Ai et al. [25] found that higher prayer frequencies were associated to reduced complications following coronary artery bypass graft surgery but not to length of hospital stay. This finding seems especially significant considering that a behavioral aspect could be exerting an influence on an important physical outcome. 
The same group of researchers evaluated patients postCABG with promising results. In 2002 [26], the group evaluated prayer for oneself and found that it was directly associated with optimism and healthier effect. The same was noted in 2007 when prayer coping was correlated to less preoperative stress symptoms [27]. Notably, even after a oneyear followup, results of prayer were maintained including lower rates of depression and general distress [28].

A study examining the relationship between prayer and quality of life pointed to a mediation of cognitive coping and perceived social support [29].

Nevertheless, another study conducted in 2007 [30] evaluating community elderly found that prayer frequencies did not predict change in depressive symptoms after 3 years of followup.

Study Limitations. There are several limitations with respect to prayer studies. First, prayer can have an adaptative and/or a maladaptative coping response. For example, praying with an attitude of waiting for a miracle to happen or relying on doctors to find a cure for one's ailment can have a negative impact on health whereas active religiousness can have positive outcomes. Thus, it is necessary to evaluate whether prayer in fact has a negative or positive impact on the person. Second, prayer is not standardized, and approaches can vary depending on the religious affiliation. Third, some measures of prayer, such as prevalence of prayer and frequency of prayer, are simplistic measures which may not reflect the whole process of faith and coping.

Future Directions. In our systematic review, concerns over the lack of studies should be highlighted. The majority of cases were cardiological patients while only one study evaluated community elderly [30]. We believe that the numerous studies in the literature dealing with intercessory prayer should be superseded instead by evaluating praying for oneself (easy to control and represents active religiousness). The long-term benefits or malefits of such "intervention" should be analyzed through representative population cohort studies designed with this specific objective, and not as a subpart of larger studies.

Conclusion. Prayer for oneself appears to be linked to better health outcomes such as lower rate of complications after CABG, improved optimism, and reduced stress. However, lack of rigorous methodological studies and highly selected populations preclude confirmation of this hypothesis at present.

\section{Laying on of Hands}

Hypothesis 2. Laying on of hands is associated with better health outcomes.

Background. Also known as an imposition of hands or laying on of hands, the therapeutic touch is a common issue in medicine and nursing today. Some authors have defined this under "biofield therapies" which "are those modalities including Reiki, qigong therapy, and Therapeutic Touch, among others, performed by trained practitioners who manually and/or via intent, interact with energy fields of the patient" [31].

Biofield therapies are among the most widely used complementary therapies, and demand for them has been growing [32]. The interest in this issue prompted the University of Arizona to create the "Center for Frontier Medicine in Biofield Science."

Spiritist View. According to Spiritism, laying on of hands is defined as "an energy transfusion, changing the cellular field" [22, 23] and "a psychic energy transfusion" [33]. Further, regarding imposition of hands energies $[34,35]$, "The spiritual fluids, which constitute one of the states of the universal cosmic fluid, are then the atmosphere of spiritual beings. It is the element whence they draw the materials with which they operate,- the place where special phenomena take place, perceptible to the sight and hearing of the spirit, but which escapes the carnal senses which are impressed alone by tangible matter." Kardec also pointed [7], "Fluidic matter produces a similar effect to medicinal matter, only with a difference (owing to the former's greater depth of penetration given the tenuity of its constituents) of acting more directly on primary molecules of the organism than on larger molecules of tangible matter.... Its qualities are affected by thought."

Scientific Evidence. In the following analysis, we decided to include only comparative studies evaluating therapeutic touch (TT)/laying on of hands (LOOH) and sham (mimic) TT/LOOH. Groups not submitted to TT/LOOH or mimic TT/LOOH were excluded due to the placebo effect of imposition of hands. A total of 11 clinical trials were retrieved for the final analysis (Table 3).

Three studies were conducted in long-term care and nursing home residents, showing reduced behavioral symptoms in dementia patients including restlessness, stress (lower morning cortisol) [36], physical nonaggressive behaviors [37], and wandering, tapping, banging, pacing, and walking [38].

Another seven studies evaluated pain measures. Results indicated decreased pain in patients with cancer undergoing chemotherapy [39] as well as those with knee osteoarthritis [40], burns [41], and headache [42]. Nevertheless, some studies revealed a nonsignificant difference in patients submitted to stereotactic biopsy [43], carpal tunnel [44] and those experiencing postoperative pain [45].

Regarding anxiety, two studies showed no difference between TT and mimic TT $[43,46]$, and one study observed improvement on the visual analogic scale for anxiety in burn patients [41].

Additionally, in order to minimize the placebo effect, in vitro studies were performed showing an increase in human cells in cultures [47], DNA synthesis and mineralization of human osteoblasts [48], and elevated blood hemoglobin and hematocrit Levels [49]. 
TABLE 3: Hypothesis 2: laying on of hands is associated with better health outcomes.

\begin{tabular}{|c|c|c|c|c|c|c|c|}
\hline Study & Sample & Follow-up & $\begin{array}{l}\text { Type of } \\
\text { Study }\end{array}$ & Predictor & Outcome & Results & $\begin{array}{l}\text { Jadad } \\
\text { Score } \\
\end{array}$ \\
\hline $\begin{array}{l}\text { Woods } \\
\text { et al. [36] }\end{array}$ & $\begin{array}{l}65 \text { nursing } \\
\text { home residents }\end{array}$ & 3 days & RCT, B & TT Vs PLTT & $\begin{array}{l}\text { Behavioral } \\
\text { symptoms } \\
\text { and cortisol }\end{array}$ & $\begin{array}{l}\text { Restlessness was significantly reduced in the } \\
\text { experimental group compared to the control } \\
\text { group }(P=.03) \text {. There was a significant } \\
\text { difference in morning cortisol variability } \\
\text { among groups across time periods }(<.0001)\end{array}$ & 5 \\
\hline $\begin{array}{l}\text { Gomes } \\
\text { et al. [46] }\end{array}$ & $\begin{array}{l}42 \text { university } \\
\text { students }\end{array}$ & 3 sessions & RCT, B & TT Vs PLTT & Anxiety & $\begin{array}{l}\text { The analysis of the data showed a statistically } \\
\text { significant reduction of the state of anxiety } \\
\text { in both groups, with } P<.05\end{array}$ & 4 \\
\hline $\begin{array}{l}\text { Aghabati } \\
\text { et al. [39] }\end{array}$ & $\begin{array}{l}90 \text { cancer } \\
\text { patients } \\
\text { undergoing } \\
\text { chemotherapy }\end{array}$ & 5 days & RCT, B & $\begin{array}{l}\text { TT Vs PLTT } \\
\text { Vs UC }\end{array}$ & $\begin{array}{l}\text { Pain and } \\
\text { Fatigue }\end{array}$ & $\begin{array}{l}\text { The TT was more effective in decreasing pain } \\
\text { and fatigue of the cancer patients undergoing } \\
\text { chemotherapy than the usual care group, } \\
\text { while the placebo group indicated a } \\
\text { decreasing trend in pain and fatigue scores } \\
\text { compared with the usual care group }\end{array}$ & 5 \\
\hline $\begin{array}{l}\text { Hawranik } \\
\text { et al. [37] }\end{array}$ & $\begin{array}{l}51 \text { residents of } \\
\text { a long term } \\
\text { care facility }\end{array}$ & 5 days & RCT, B & $\begin{array}{l}\text { TT Vs PLTT } \\
\text { Vs UC }\end{array}$ & $\begin{array}{l}\text { Disruptive } \\
\text { behavior }\end{array}$ & $\begin{array}{l}\text { Physical nonaggressive behaviors decreased } \\
\text { significantly in those residents who received } \\
\text { therapeutic touch compared with those who } \\
\text { received the simulated version and the usual } \\
\text { care. No significant differences in physically } \\
\text { aggressive and verbally agitated behaviors } \\
\text { were observed across the three study groups }\end{array}$ & 4 \\
\hline $\begin{array}{l}\text { Frank } \\
\text { et al. [43] }\end{array}$ & $\begin{array}{l}82 \text { patients } \\
\text { submitted to } \\
\text { stereotactic } \\
\text { breast biopsy }\end{array}$ & $\begin{array}{l}\text { Immediately } \\
\text { after } \\
\text { procedure }\end{array}$ & RCT, B & TT Vs PLTT & $\begin{array}{l}\text { Pain and } \\
\text { anxiety }\end{array}$ & $\begin{array}{l}\text { No significant differences between the arms } \\
\text { were seen regarding postbiopsy pain } \\
(P=.95) \text { and anxiety }(P=.66)\end{array}$ & 5 \\
\hline $\begin{array}{l}\text { Woods } \\
\text { et al. [38] }\end{array}$ & $\begin{array}{l}57 \text { nursing } \\
\text { home residents }\end{array}$ & 6 days & RCT, B & $\begin{array}{l}\text { TT Vs PLTT } \\
\text { Vs UC }\end{array}$ & $\begin{array}{l}\text { Overall } \\
\text { behavioral } \\
\text { symptoms of } \\
\text { dementia, }\end{array}$ & $\begin{array}{l}\text { The TT (significant) was more effective in } \\
\text { decreasing behavioral symptoms of dementia } \\
\text { than usual care, while the placebo group } \\
\text { indicated a decreasing trend in behavioral } \\
\text { symptoms of dementia compared to usual } \\
\text { care }\end{array}$ & 4 \\
\hline $\begin{array}{l}\text { Blankfield } \\
\text { et al. [44] }\end{array}$ & $\begin{array}{l}21 \text { participants } \\
\text { with carpal } \\
\text { tunnel } \\
\text { syndrome }\end{array}$ & 6 weeks & RCT, B & TT Vs PLTT & $\begin{array}{l}\text { visual analog } \\
\text { assessments } \\
\text { of pain and } \\
\text { relaxation }\end{array}$ & $\begin{array}{l}\text { Changes in pain scores and relaxation scores } \\
\text { did not differ between participants in the TT } \\
\text { group and participants in the PLTT group }\end{array}$ & 4 \\
\hline $\begin{array}{l}\text { Gordon } \\
\text { et al. [40] }\end{array}$ & $\begin{array}{l}25 \text { patients } \\
\text { with knee } \\
\text { osteoarthritis }\end{array}$ & & RCT, B & $\begin{array}{l}\text { TT Vs PLTT } \\
\text { Vs UC }\end{array}$ & $\begin{array}{l}\text { Pain and } \\
\text { functional } \\
\text { status }\end{array}$ & $\begin{array}{l}\text { The treatment group had significantly } \\
\text { decreased pain and improved function as } \\
\text { compared with the placebo and control } \\
\text { groups }\end{array}$ & 4 \\
\hline $\begin{array}{l}\text { Turner } \\
\text { et al. [41] }\end{array}$ & $\begin{array}{l}99 \text { burn } \\
\text { patients }\end{array}$ & 6 days & RCT, B & TT Vs PLTT & $\begin{array}{l}\text { Pain, Anxiety } \\
\text { and } \\
\text { satisfaction } \\
\text { with life }\end{array}$ & $\begin{array}{l}\text { Subjects who received TT reported } \\
\text { significantly greater reduction in pain and } \\
\text { greater reduction in anxiety on the Visual } \\
\text { Analogue Scale for Anxiety than did those } \\
\text { who received sham TT }\end{array}$ & 4 \\
\hline $\begin{array}{l}\text { Meehan } \\
{[45]}\end{array}$ & $\begin{array}{l}108 \\
\text { postoperative } \\
\text { patients }\end{array}$ & 1 hour & RCT, B & $\begin{array}{l}\text { TT Vs PLTT } \\
\text { Vs UC }\end{array}$ & $\begin{array}{l}\text { Postoperative } \\
\text { Pain }\end{array}$ & $\begin{array}{l}\text { Therapeutic touch did not significantly } \\
\text { decrease postoperative pain compared to the } \\
\text { placebo control intervention }\end{array}$ & 4 \\
\hline $\begin{array}{l}\text { Keller and } \\
\text { Bzdek [42] }\end{array}$ & $\begin{array}{l}60 \text { patients } \\
\text { with TTH }\end{array}$ & 4 hours & RCT, B & TT Vs PLTT & Pain & $\begin{array}{l}90 \% \text { of the subjects exposed to TT } \\
\text { experienced a sustained reduction in } \\
\text { headache pain, } P<.0001\end{array}$ & 4 \\
\hline
\end{tabular}

TT: therapeutic touch; PLTT: placebo therapeutic touch; UC: usual care; B: blind; RCT: randomized controlled trial; TTH: tension-type headache. 
Study Limitations. Therapeutic touch studies have been widely reported in the medical literature. However, most studies involved small, convenient samples and had nonrandomized controlled and blind designs. Another concern is the short followup (days), evaluating only acute outcomes such as pain and anxiety. Moreover, many studies used visual analogic scales preventing more complex analysis of this field.

Future Directions. In our opinion, future studies should focus on the differences among therapeutic touch, a defined technique developed by Krieger [50], and other types of hand imposition such as the Spiritist "passe," Johrei and Reiki. Another aspect that should be evaluated is the comparison of intentional laying on of hands and healing techniques based on a "high healing" power. For example, a study conducted in Austria [51] sought to assess the difference in efficacy between a healer and an actor. However, the healer became unblinded and withdrew from the study after the first session, and therefore the results are misleading. This was a valuable attempt to understand the role of therapies including Johrei, Heike, and Spiritist "passé." Furthermore, another future direction is focusing on the identification of which types of energies were irradiated from the imposition of hands. The chronic use of TT should also be evaluated in representative populations.

Conclusion. The body of evidence accumulated to date points to a positive effect of therapeutic touch on behavioral symptoms and in most pain studies, while presenting contradictory results regarding anxiety. Some experimental studies have also shown promising results on cells (human cultures, osteoblasts, red blood cells) further supporting this hypothesis.

\section{Fluidotherapy (Fluidic Water)}

Hypothesis 3. Magnetized water is associated with better health outcomes.

Background. The concept of magnetized water was studied by Masaru Emoto, whose team carried out a study which was tested under double-blind conditions. The theory that water "treated" with an intention can affect ice crystals formed from that water was tested, and the results revealed that crystals produced from the treated water were given higher scores for aesthetic appeal than those from the control water $(P=.001)$ thus lending support to the hypothesis [52]. In 2004, the same author [53] wrote an article entitled, "Healing with water" published in the Journal of Alternative and Complementary Medicine, describing the power of healing through water.

Spiritist View. According to the Spiritist view [34, 35], "the most simple agents - water, for example — can acquire powerful and effective qualities under the action of the spiritual or magnetic fluid, for which they serve as vehicle, or reservoir." Furthermore, Spirit Emmanuel in the book
"Follow me" ("Segue-me") [54] stated, “- Water can acquire subtle or "fluidic" qualities upon being induced by the agent of Will. Magnetized or fluidified water. The agent of fluidified water consists of the properties instilled in it and possesses medicinal power which acts on the perispirit and indirectly contributes to restoring the physical body."

Scientific Evidence. Only two studies remained after applying of rigorous exclusion criteria. Curiously, both were from the odontology field. In 1998, Johson et al. [55] evaluated the effects of a magnetized water oral irrigator on plaque, calculus, and gingival health. The result showed that the group using magnetized water resulted in 64\% less calculus in comparison to the control group where this reduction reached statistical significance, corroborating the results found by Watt et al. [56].

Some experimental studies were conducted on this issue. In Brazil, a study carried out by Savieto et al. [57] evaluated the effects of the consumption of water treated with therapeutic touch on the healing of uniform wounds in the skin of mice. The average wound size in the experimental group was found to be consistently smaller than that in the control group, and the difference among the measures obtained in the two groups reached statistical significance. The authors' conclusion was that the water undergoing therapeutic touch can serve as a complementary therapy in wound treatment. Similar results were found in other two studies from the same authors $[58,59]$. In China, a study conducted by Yi-Long et al. [60] studied the effect of magnetized water on enzyme activities and showed that the activity of glutamate decarboxylase was increased by $30 \%$ in magnetized water.

However, few studies have assessed this hypothesis in humans. None of the articles on studies in humans were selected in this systematic review due to serious methodological issues. Nevertheless, we decided to cite some references. Merkulova and Mikhel'son [61] from Russia tested the action of magnetized water on the quality of health at a sanatorium, reporting positive results, and also tested the biological and bactericidal action of magnetized water [62]. In 1987, scientists from China tested the effect of magnetic water on urinary calculi [63] and for prevention of diarrhea [64] reporting successful outcomes.

Study Limitations. Several limitations should be outlined pertaining to the studies focusing on this hypothesis. First, there is a lack of sound methodological studies in the field. Second, few researchers are currently studying this issue, and third, there are a huge number of pseudoscientific statements made to the lay public, hampering a more serious analysis.

Future Directions. There are few studies in the literature assessing this issue. Most studies are based on noncontrolled observational studies conducted between 20 and 30 years ago. It seems that fluidic (magnetized) water has been left to the wayside in modern medical science. Such a simple procedure must be analyzed with serious scientific rigor in order to confirm beneficial effects or otherwise. The future 
direction for this field should be based on well-conducted clinical trials in laboratory animals and humans. There are no contraindications for the use of water, and in addition it represents a low-cost and highly accessible resource.

Conclusion. There is a lack of well-conducted controlled, double-blind studies on magnetized/fluidic water. Some observational data from the 1980 s points to potential beneficial effects in humans, and studies in rats have shown promising results. However, currently available evidence neither supports or rejects this hypothesis. Clearly, further studies are warranted on this issue.

\section{Charity (Volunteerism)}

Hypothesis 4. Volunteerism is associated to better health outcomes.

Background. The association between charity and health is gaining increasing scientific recognition. Charity is defined by the Merriam-Webster dictionary as, "benevolent goodwill toward" and "generosity and helpfulness especially toward the needy or suffering." Post [65] wrote an article called "It's Good to be Good: Health and the Generous Heart" where he believes that "the evidence supports that one of the healthiest things a person can do is to step back from self-preoccupation and self-worry, as well as from hostile and bitter emotions, and there is no more obvious way of doing this than focusing attention on helping others."

In the early 1970s, the "helper therapy" principle was noted in a few leading psychiatry journals as professional researchers found that helping others was beneficial in a variety of settings. Luks [66], in a survey of thousands of volunteers across the United States, found that people who helped others consistently reported better health than peers in the same age group.

Spiritist View. Kardec wrote [67], "without charity, there is no salvation" and that the "greatest model of charity and moral perfection that we have to follow is Jesus" [3]. Charity according to Spiritism [3] is, "Benevolence for everyone, indulgence for the imperfections of others, forgiveness of injuries."

Scientific Evidence. Ten studies scored more than 6 points on the Newcastle-Ottawa scale and were included in the final model (Table 4). All studies were cohort type allowing causeeffect conclusions. Three studies analyzed the relationship between volunteering and mortality. Those who frequently volunteered had significantly reduced mortality compared to nonvolunteers $[68,69]$. Additionally, years of volunteering were also associated with lower mortality. In a study carried out on a 7-year cohort, those who volunteered for 10 to 14 years had a lower mortality risk compared to nonvolunteers [70]. These results remained statistically significant even after controlling for sociodemographic aspects such as, age, sex, income, race and also for physical and social aspects.
Most studies point to an association between volunteering and better self-reported health [71-74], well-being [73], and life satisfaction [75]. This relationship includes a 47-year followup of 4000 women and men graduated from Wisconsin high schools [73]. According to the authors, "Using the Wisconsin Longitudinal Study, we have once again demonstrated that volunteering is positively related to psychological wellbeing. In addition, we provide strong evidence that the relationship is causal, based on analyses controlling for well-being in 1992 when predicting essentially the same measure in 2004."

Some articles analyzed the association between mood disorders, especially depression. Two studies [71, 74] show an inverse relationship between volunteerism and depression in the adult population, independently of age while two studies [76, 77] demonstrated the same association in elderly. Particularly in depression, older persons seem to benefit more from volunteering as an alternative to retirement.

Finally, two studies were conducted regarding physical health. Volunteers tend to have less functional disability [74] and engage more in physical activity [71].

Study Limitations. Some self-reported health measures such as self-rated health and well-being may not adequately analyze the complexities of the human state. We believe that the use of validated and multidimensional scales could enable better representation of these aspects. Another limitation is that volunteerism includes a variety of different aspects, such as church-based, financial, and social volunteerism, that should be analyzed separately and not together as a whole. Furthermore, the majority of studies, not reported here, are cross-sectional and therefore do not examine cause-effect relationships.

Future Directions. A future direction for this field is the analysis of which mechanisms are involved in this causal relationship. Is it the good feeling that decreases cortisol or proinflammatory levels and reduces mortality in this sample? Or could another mechanism be involved? This represents a vast area for future research. Another future line of research entails analyzing other factors such as stress, anxiety, phobic disorders, hospitalization, and cerebro-cardiovascular outcomes.

Conclusion. Evidence supporting a relationship between volunteerism and health outcomes is moderate to strong, particularly concerning survival, well-being, health status and depression in elderly. The mechanisms underlying this relationship warrant further investigation.

\section{Spirit Education (The Role of Virtuous Life and Positive Affect)}

Hypothesis 5. Virtuous life and positive affect are associated with better health outcomes (Table 5 ). 
TABLE 4: Hypothesis 4: Volunteering is associated with better health outcomes.

\begin{tabular}{|c|c|c|c|c|c|c|}
\hline Study & Sample & $\begin{array}{l}\text { Cohort } \\
\text { followup }\end{array}$ & Predictor & Outcome & Results & $\begin{array}{l}\text { Newcastle- } \\
\text { Otawa } \\
\text { grade }\end{array}$ \\
\hline $\begin{array}{l}\text { Pillemer } \\
\text { et al. [71] }\end{array}$ & $\begin{array}{l}2630 \text { noninsti- } \\
\text { tutionalized } \\
\text { adult } \\
\text { population }\end{array}$ & 20 years & $\begin{array}{l}\text { Volunteering } \\
\text { (environmen- } \\
\text { tal versus } \\
\text { other) }\end{array}$ & $\begin{array}{l}\text { Physical activity, } \\
\text { self-reported } \\
\text { health, and } \\
\text { depressive } \\
\text { symptoms }\end{array}$ & $\begin{array}{l}\text { Midlife environmental volunteering was } \\
\text { significantly associated with physical } \\
\text { activity, self-reported health, and less } \\
\text { depressive symptoms }\end{array}$ & 7 \\
\hline $\begin{array}{l}\text { Kim and } \\
\text { Pai [77] }\end{array}$ & $\begin{array}{l}2562 \text { adults } 25 \\
\text { years or older }\end{array}$ & 8 years & $\begin{array}{l}\text { Volunteering } \\
\text { (yes/no) and } \\
\text { frequency of } \\
\text { volunteering }\end{array}$ & Depression & $\begin{array}{l}\text { Overall, volunteering did not predict } \\
\text { trajectories of depression; however, it } \\
\text { affects the decline of depression for } \\
\text { individuals above age } 65\end{array}$ & 7 \\
\hline Krause [72] & 681 older adults & 6 years & $\begin{array}{l}\text { Volunteering } \\
\text { and providing } \\
\text { tangible goods } \\
\text { and services }\end{array}$ & $\begin{array}{l}\text { Self-reported } \\
\text { health }\end{array}$ & $\begin{array}{l}\text { provision of tangible goods and services } \\
\text { (food, clothing, shelter) to people in need } \\
\text { were associated with better health but } \\
\text { only for study participants who were } \\
\text { more deeply committed to their faith }\end{array}$ & 7 \\
\hline Ayalon [70] & $\begin{array}{l}5055 \text { Israelis } \\
\text { aged } 60 \text { years } \\
\text { and older }\end{array}$ & 7 years & Volunteering & Mortality & $\begin{array}{l}\text { Those who volunteered for } 10 \text { to } 14 \text { years } \\
\text { had a reduced mortality risk relative to } \\
\text { nonvolunteers. In addition, those who } \\
\text { volunteered privately, not as part of an } \\
\text { official organization, also had a reduced } \\
\text { mortality risk compared to nonvolunteers }\end{array}$ & 9 \\
\hline $\begin{array}{l}\text { Piliavin and } \\
\text { Siegl [73] }\end{array}$ & $\begin{array}{l}4000 \text { women } \\
\text { and men who } \\
\text { graduated from } \\
\text { Wisconsin high } \\
\text { schools }\end{array}$ & 47 years & Volunteering & $\begin{array}{l}\text { Psychological } \\
\text { well-being and } \\
\text { self-reported } \\
\text { health }\end{array}$ & $\begin{array}{l}\text { Both consistency of volunteering over } \\
\text { time and diversity of participation are } \\
\text { significantly related to well-being and } \\
\text { self-reported health }\end{array}$ & 8 \\
\hline $\begin{array}{l}\text { Harris and } \\
\text { Thoresen } \\
{[68]}\end{array}$ & $\begin{array}{l}7527 \text { American } \\
\text { community- } \\
\text { dwelling older } \\
\text { people }\end{array}$ & $\begin{array}{l}96 \\
\text { months }\end{array}$ & Volunteering & Mortality & $\begin{array}{l}\text { Frequent volunteers had significantly } \\
\text { reduced mortality compared to } \\
\text { nonvolunteers }\end{array}$ & 8 \\
\hline $\begin{array}{l}\text { Morrow- } \\
\text { Howell } \\
\text { et al. [74] }\end{array}$ & 3617 adults & 8 years & Volunteering & $\begin{array}{l}\text { Self-rated health, } \\
\text { functional } \\
\text { dependency, and } \\
\text { depression }\end{array}$ & $\begin{array}{l}\text { Older adults who volunteer and who } \\
\text { engage in more hours of volunteering } \\
\text { report higher levels of well-being } \\
\text { (including less depression, less functional } \\
\text { disability, and better health) }\end{array}$ & 8 \\
\hline $\begin{array}{l}\text { Musick and } \\
\text { Wilson [76] }\end{array}$ & $\begin{array}{l}2348 \text { non- } \\
\text { institutionalized } \\
\text { persons aged } 25 \\
\text { and older }\end{array}$ & 5 years & $\begin{array}{l}\text { Volunteering } \\
\text { work }\end{array}$ & Depression & $\begin{array}{l}\text { No association between volunteering and } \\
\text { depression in the younger subsample; } \\
\text { only for the } 65+\text { age group did } \\
\text { volunteering have a negative effect on } \\
\text { depression, while prolonged exposure to } \\
\text { volunteering benefits both populations }\end{array}$ & 8 \\
\hline $\begin{array}{l}\text { Van } \\
\text { Willigen } \\
{[75]}\end{array}$ & $\begin{array}{l}2867 \text { adults } \\
\text { aged } 25 \text { years or } \\
\text { older }\end{array}$ & 3 years & Volunteering & $\begin{array}{l}\text { Perceived health } \\
\text { and life } \\
\text { satisfaction }\end{array}$ & $\begin{array}{l}\text { The volunteer role is positively associated } \\
\text { with life satisfaction and with perceived } \\
\text { health }\end{array}$ & 8 \\
\hline $\begin{array}{l}\text { Musick } \\
\text { et al. [69] }\end{array}$ & $\begin{array}{l}2348 \text { noninsti- } \\
\text { tutionalized } \\
\text { Persons aged } 25 \\
\text { and older }\end{array}$ & 8 years & Volunteering & Mortality & $\begin{array}{l}\text { Volunteering has a protective effect on } \\
\text { mortality among those who volunteered } \\
\text { for one organization or for forty hours or } \\
\text { less over the past year }\end{array}$ & 8 \\
\hline
\end{tabular}

Background. This field is gaining attention in the medical literature. A study by Williams et al. [78] showed that proneness to anger places normotensive middle-aged menand women at significant risk for CHD morbidity and death, independent of the established biological risk factors.
In his book "Forgive For Good," Luskin [79] of Stanford University began studying Protestant and Catholic mothers whose children were killed in political-religious clashes. Forgiveness interventions lowered blood pressure, reduced stress hormones, improved depression, and enhanced selfreported health. 
TABLe 5: Hypothesis 5: Virtuous life and Positive affect is associated with better health outcomes.

\begin{tabular}{|c|c|c|c|c|c|c|c|}
\hline Study & Sample & $\begin{array}{l}\text { Cohort } \\
\text { followup }\end{array}$ & Predictor & Outcome & Results & $\begin{array}{l}\text { Newcastle- } \\
\text { Otawa } \\
\text { grade }\end{array}$ & $\begin{array}{l}\text { Jadad } \\
\text { score }\end{array}$ \\
\hline $\begin{array}{l}\text { Wattanakit } \\
\text { et al. [94] }\end{array}$ & $\begin{array}{l}12,965 \\
\text { middle-aged } \\
\text { adults }\end{array}$ & 9.7 years & $\begin{array}{l}\text { Anger } \\
\text { proneness }\end{array}$ & $\begin{array}{l}\text { Peripheral } \\
\text { arterial disease } \\
(\mathrm{PAD})\end{array}$ & $\begin{array}{l}\text { Positive association between anger } \\
\text { proneness and incident PAD }\end{array}$ & 8 & - \\
\hline $\begin{array}{l}\text { Williams } \\
\text { et al. [78] }\end{array}$ & 12986 adults & $\begin{array}{l}53 \\
\text { months }\end{array}$ & trait anger & $\begin{array}{l}\text { Coronary } \\
\text { heart disease } \\
(\mathrm{CHD})\end{array}$ & $\begin{array}{l}\text { High trait anger, compared with } \\
\text { their low anger counterparts, were } \\
\text { at increased risk of CHD }\end{array}$ & 8 & - \\
\hline $\begin{array}{l}\mathrm{Xu} \text { and } \\
\text { Roberts [82] }\end{array}$ & 6856 adults & 28 years & $\begin{array}{l}\text { Positive } \\
\text { Feelings }\end{array}$ & Mortality & $\begin{array}{l}\text { Subjective well-being, positive } \\
\text { feelings, life satisfaction } \\
\text { significantly predicted lowered } \\
\text { risks of all-cause and } \\
\text { natural-cause mortality }\end{array}$ & 8 & - \\
\hline $\begin{array}{l}\text { Danner } \\
\text { et al. }[85]\end{array}$ & $\begin{array}{l}180 \text { Catholic } \\
\text { nuns }\end{array}$ & $\begin{array}{l}53 \text { to } 73 \\
\text { years }\end{array}$ & $\begin{array}{l}\text { Positive } \\
\text { emotional } \\
\text { content in } \\
\text { early-life } \\
\text { autobiographies }\end{array}$ & Mortality & $\begin{array}{l}\text { Positive emotional content in } \\
\text { early-life autobiographies was } \\
\text { strongly associated with longevity } \\
6 \text { decades later }\end{array}$ & 7 & - \\
\hline $\begin{array}{l}\text { Davidson } \\
\text { et al. [86] }\end{array}$ & 1739 adults & 10 years & positive affect & $\begin{array}{l}\text { Cardiovascular } \\
\text { events }\end{array}$ & $\begin{array}{l}\text { Increased positive affect was } \\
\text { protective against } 10 \text {-year } \\
\text { incident CHD }\end{array}$ & 8 & - \\
\hline $\begin{array}{l}\text { Versteeg } \\
\text { et al. [92] }\end{array}$ & $\begin{array}{l}562 \mathrm{PCI} \\
\text { patients }\end{array}$ & 1 year & $\begin{array}{l}\text { negative and } \\
\text { positive affect }\end{array}$ & $\begin{array}{l}\text { Health status } \\
\text { after PCI }\end{array}$ & $\begin{array}{l}\text { Baseline negative and positive } \\
\text { affect contributes independently } \\
\text { to patient-reported health status } \\
12 \text { months post-PCI }\end{array}$ & 7 & - \\
\hline $\begin{array}{l}\text { Park-Lee } \\
\text { et al. }[88]\end{array}$ & $\begin{array}{l}337 \text { caregiver } \\
\text { and } 617 \\
\text { noncaregiver }\end{array}$ & 2 years & $\begin{array}{l}\text { High and low } \\
\text { positive affect }\end{array}$ & Frailty & $\begin{array}{l}\text { Frailty risk was lower in } \\
\text { respondents with high positive } \\
\text { affect than in those with low } \\
\text { positive affect in the total sample }\end{array}$ & 7 & - \\
\hline $\begin{array}{l}\text { Moskowitz } \\
\text { et al. [83] }\end{array}$ & $\begin{array}{l}715 \text { diabetes } \\
\text { patients and } \\
2673 \text { controls }\end{array}$ & & Positive affect & Mortality & $\begin{array}{l}\text { Positive affect was significantly } \\
\text { associated with lower risk of } \\
\text { all-cause mortality in people with } \\
\text { diabetes, but not in control group }\end{array}$ & 7 & - \\
\hline $\begin{array}{l}\text { Denollet } \\
\text { et al. [87] }\end{array}$ & $\begin{array}{l}874 \text { PCI } \\
\text { patients }\end{array}$ & 2 years & Positive affect & $\begin{array}{l}\text { Death or } \\
\text { myocardial } \\
\text { infarction } \\
\text { post-PCI }\end{array}$ & $\begin{array}{l}\text { Reduced positive affect } \\
\text { independently predicted } \\
\text { death/MI following stent } \\
\text { implantation }\end{array}$ & 8 & - \\
\hline $\begin{array}{l}\text { Fredman } \\
\text { et al. }[91]\end{array}$ & $\begin{array}{l}432 \text { elderly } \\
\text { hospitalized } \\
\text { for hip fracture }\end{array}$ & 2 years & $\begin{array}{l}\text { High and low } \\
\text { positive affect }\end{array}$ & $\begin{array}{l}\text { Performance- } \\
\text { based } \\
\text { functioning } \\
\text { after hip } \\
\text { fracture }\end{array}$ & $\begin{array}{l}\text { High positive affect seems to have } \\
\text { a beneficial influence on } \\
\text { performance-based functioning } \\
\text { after hip fracture }\end{array}$ & 8 & - \\
\hline $\begin{array}{l}\text { Ostir et al. } \\
{[89]}\end{array}$ & $\begin{array}{l}1558 \text { initially } \\
\text { nonfrail older }\end{array}$ & 7 years & Positive affect & $\begin{array}{l}\text { Onset of } \\
\text { frailty }\end{array}$ & $\begin{array}{l}\text { positive affect is protective against } \\
\text { the functional and physical } \\
\text { decline associated with frailty }\end{array}$ & 8 & - \\
\hline $\begin{array}{l}\text { Fisher et al. } \\
{[90]}\end{array}$ & $\begin{array}{l}1084 \text { noninsti- } \\
\text { tutionalized } \\
\text { elderly with } \\
\text { arthritis }\end{array}$ & 2 years & $\begin{array}{l}\text { positive and } \\
\text { negative affect }\end{array}$ & $\begin{array}{l}\text { Functional } \\
\text { ability }\end{array}$ & $\begin{array}{l}\text { High positive affect was } \\
\text { associated with lower incidence of } \\
\text { ADL disability in older Mexican } \\
\text { Americans with self-reported } \\
\text { physician-diagnosed arthritis }\end{array}$ & 7 & - \\
\hline $\begin{array}{l}\text { Moskowitz } \\
{[84]}\end{array}$ & $\begin{array}{l}407 \text { men who } \\
\text { were HIV+ }\end{array}$ & 2 years & Positive affect & $\begin{array}{l}\text { AIDS } \\
\text { mortality }\end{array}$ & $\begin{array}{l}\text { Positive affect was significantly } \\
\text { associated with lower risk of AIDS } \\
\text { mortality }\end{array}$ & 7 & - \\
\hline $\begin{array}{l}\text { Skodol et al. } \\
{[93]}\end{array}$ & $\begin{array}{l}520 \text { patients } \\
\text { with } \\
\text { personality } \\
\text { disorders }\end{array}$ & 4 years & $\begin{array}{l}\text { Positive } \\
\text { childhood } \\
\text { experiences }\end{array}$ & $\begin{array}{l}\text { Remission } \\
\text { from } \\
\text { personality } \\
\text { disorders }\end{array}$ & $\begin{array}{l}\text { Positive childhood experiences } \\
\text { were significantly associated with } \\
\text { remission from avoidant and } \\
\text { schizotypal personality disorders }\end{array}$ & 7 & - \\
\hline
\end{tabular}


TABle 5: Continued.

\begin{tabular}{|c|c|c|c|c|c|c|c|}
\hline Study & Sample & $\begin{array}{l}\text { Cohort } \\
\text { followup }\end{array}$ & Predictor & Outcome & Results & $\begin{array}{l}\text { Newcastle- } \\
\text { Otawa } \\
\text { grade }\end{array}$ & $\begin{array}{l}\text { Jadad } \\
\text { score }\end{array}$ \\
\hline Yi et al. [95] & $\begin{array}{l}111 \text { patients } \\
\text { with diabetes }\end{array}$ & 1 year & Resilience & $\begin{array}{l}\mathrm{HbA}(1 \mathrm{c}) \text { and } \\
\text { self-care } \\
\text { behaviours }\end{array}$ & $\begin{array}{l}\text { Those with low or moderate } \\
\text { resilience levels showed a strong } \\
\text { association between rising distress } \\
\text { and worsening HbA (1c) across } \\
\text { time }\end{array}$ & 7 & - \\
\hline $\begin{array}{l}\text { Walter- } \\
\text { Ginzburg } \\
\text { et al. [96] }\end{array}$ & $\begin{array}{l}960 \text { Israeli Jews } \\
\text { aged } 75-94\end{array}$ & $\begin{array}{l} \pm 3 \\
\text { years }\end{array}$ & Resilience & Mortality & Resilience predicted less mortality & 8 & - \\
\hline $\begin{array}{l}\text { Poulin and } \\
\text { Cohen Silver } \\
{[103]}\end{array}$ & 2138 adults & 2 years & $\begin{array}{l}\text { Benevolence } \\
\text { (Goodness of } \\
\text { the World) }\end{array}$ & Well-being & $\begin{array}{l}\text { Benevolence beliefs were } \\
\text { positively associated with } \\
\text { well-being and that these } \\
\text { associations were stronger with } \\
\text { increasing age }\end{array}$ & 7 & - \\
\hline $\begin{array}{l}\text { Buchanan } \\
\text { and Bardi } \\
{[99]}\end{array}$ & 86 participants & 10 days & Kind acts & $\begin{array}{l}\text { Satisfaction } \\
\text { with life }\end{array}$ & $\begin{array}{l}\text { Kind acts, performed daily over as } \\
\text { little as } 10 \text { days, increased life } \\
\text { satisfaction }\end{array}$ & 7 & - \\
\hline $\begin{array}{l}\text { Otake et al. } \\
{[100]}\end{array}$ & $\begin{array}{l}119 \\
\text { participants }\end{array}$ & 1 week & $\begin{array}{l}\text { Counting } \\
\text { Kindness }\end{array}$ & Happiness & $\begin{array}{l}\text { People counting kindnesses } \\
\text { increased people's subjective } \\
\text { happiness }\end{array}$ & 7 & - \\
\hline $\begin{array}{l}\text { Carson et al. } \\
{[102]}\end{array}$ & $\begin{array}{l}43 \text { patients } \\
\text { with chronic } \\
\text { low back pain }\end{array}$ & 8 weeks & $\begin{array}{l}\text { Loving- } \\
\text { kindness } \\
\text { meditation }\end{array}$ & $\begin{array}{l}\text { Pain, anger } \\
\text { and } \\
\text { psychological } \\
\text { distress }\end{array}$ & $\begin{array}{l}\text { Loving-kindness program } \\
\text { reduced pain, anger, and } \\
\text { psychological distress in patients } \\
\text { with persistent low back pain }\end{array}$ & - & 4 \\
\hline $\begin{array}{l}\text { Hutcherson } \\
\text { et al. [101] }\end{array}$ & 93 participants & $\begin{array}{l}15 \\
\text { minutes }\end{array}$ & $\begin{array}{l}\text { Loving- } \\
\text { kindness } \\
\text { meditation }\end{array}$ & $\begin{array}{l}\text { Social } \\
\text { connectedness }\end{array}$ & $\begin{array}{l}\text { Loving-kindness meditation } \\
\text { increased feelings of social } \\
\text { connection and positivity toward } \\
\text { novel individuals }\end{array}$ & & 4 \\
\hline
\end{tabular}

PCI: percutaneous coronary intervention.

Similarly, Dillon and Wink [80] in their book "In the Course of a Lifetime" analyzed 300 preteens in the Bay Area followed every ten years since the 1920s. Those who identified compassion and generosity as important were healthier and happier 50 years later (protected from depression and some physical illnesses).

These moral values are responsible for a positive affect on dealing with life and its adversities.

Spiritist View. According to Spiritism, "the main purpose of a Spirit to return to a body of a child is to be educated again. Hence, the importance of the Spiritist Education, because to spiritually educate the children is to prepare them to face all times and all adversities of life according to the postulates of the Gospel" [81]. Jesus's lessons [67] include the cultivation of love, humility, purity, peace, goodness, mercy, benevolence, compassion, good feelings, among others. Kardec once wrote [3], "The cure may be slow, for the causes of the malady are many, but it is not impossible. It can only be effected, however, by going to the root of the evil, that is to say, by generalizing education; not the education which merely advances men in knowledge, but that which improves them morally. Education, rightly understood, is the key of moral progress, when the art of training the moral nature shall be understood as is the art of training the intellect, it will be possible to straighten a crooked nature as we straighten a crooked sapling." Spiritism also believes in the power of positive thinking as stated in the following sentence: "Bad thoughts corrupt the spiritual fluids, as deleterious miasmas corrupt the air we breath $[8,9]$."

Scientific Evidence. Twenty-one articles were selected for final analysis. Spirit education is based on moral values and seems to have a positive affect on dealing with life and its difficulties. There is strong support in the medical literature concerning positive affect on a range of health outcomes. Four studies from this systematic review analyzed the role of positive affect and mortality. All studies found a positive relationship between positive affect and overall survival in a representative sample of adults [82], diabetic patients [83], HIV patients [84], and Catholic nuns [85]. Only the comparison group of the study carried out in diabetic patients [83] found no association between positive affect and mortality. However, when the analysis was limited to those over the age of 65 , specific positive affects, in particular hopeful and enjoyed life, were significantly associated with lower risk of mortality. 
Furthermore, positive affect was related to fewer cardiovascular events in healthy adults [86] and in patients following percutaneous coronary intervention (PCI) [87] and to lower risk for frailty $[88,89]$, lower incidence of compromised activities of daily living in the elderly [90], improved performance-based functioning after hip fracture [91], better patient-reported health status post-PCI [92], and higher remission for personality disorders in adulthood [93].

Anger has been evaluated by two studies, finding anger proneness to be positively associated with incident peripheral artery disease [94], while trait anger was related to increased risk for coronary heart disease [78].

Resilience was related to lower distress and better HbA1C in diabetics [95] and predicted lower mortality in Israeli Jews [96].

A number of experimental studies support this hypothesis. In 2006 [97], volunteers were exposed to a rhinovirus or influenza virus by nasal drops and monitored for symptoms. Positive emotional style was associated with lower risk of developing an upper respiratory illness. Another study [98] reported that positive affect was inversely associated with cardiovascular reactivity, norepinephrine level, and morning rise in salivary cortisol in 328 healthy individuals during a sadness and an anger recall task.

Some studies also evaluated the role of virtuous life on health outcomes. Kindness was associated to better life satisfaction [99] and happiness [100], and a loving-kindness intervention was associated to a higher social connectedness [101] and lower back pain, anger and psychological distress [102]. Benevolence was also evaluated on a longitudinal study showing a positive relation with well-being [103].

Study Limitations. Most studies were based on the positive affect subscale of the CES-D (Center for Epidemiologic Studies Depression Scale). Other types of measurements should be employed in a bid to replicate these findings.

Future Directions. Most studies were based on positive affect or positive emotions. However, few studies assessed aspects that could foster positive affect such as benevolence, goodness, humility, peace, and compassion. Investigating the role of these moral values on health outcomes may change the view of health-disease mechanisms in the future. Additionally, better understanding the mechanisms underlying this relationship could elucidate some aspects of psychosomatic medicine.

Conclusion. There is strong support for the hypothesis that positive affect is associated with better health outcomes, especially survival, as well as lower risk of physical health disability and fewer cardiovascular events. Several experimental studies also corroborate this finding.

\section{Disobsession (Spirit Release Therapy)}

Hypothesis 6. Spirit release therapy is associated with better health outcomes.
Background. Although spirit possession cases have been reported in the medical literature [104-106], few articles on disobsession therapy have been published to date. According to a publication from the Royal College of Psychiatrists [107], "Release may be effected by encouraging the spirit to go back into the memory of its death and to understand the nature of its entrapment. This understanding, offered with empathy, usually leads to a letting go and the awakening of a desire to enter the light. This may happen on its own or accompanied by a loving spirit or group of spirits who approach and greet the lost spirit with that purpose." The Diagnostic and Statistical Manual of Mental DisordersFourth Edition [108] states, "Possession trance, a single or episodic alteration in the state of consciousness characterized by the replacement of customary sense of personal identity by a new identity is attributed to the influence of a spirit, power, deity, or other person."

According to the ICD-10 [109] (Classification of Mental and Behavioural Disorders): F44.3: trance and possession disorders mean disorders in which there is a temporary loss of both the sense of personal identity and full awareness of the surroundings; in some instances the individual acts as if taken over by another personality, spirit, deity, or "force." Attention and awareness may be limited to or concentrated upon only one or two aspects of the immediate environment, and there is often a limited but repeated set of movements, postures, and utterances. Only trance disorders that are involuntary or unwanted and that intrude into ordinary activities by occurring outside (or being a prolongation of) religious or other culturally accepted situations should be included here.

Spiritist View. The Spiritist etiologic model for mental disorders includes the negative influences of discarnated spirits (termed "obsession"). In addition to conventional medical and psychological therapeutics, Spiritist séances for disobsession are recommended, as well as "passes" (laying on of hands), prayers, and efforts to live according to ethical principles [110]. In the "Gospel according to Spiritism [67]," "obsession is the persistent action which an inferior or bad Spirit exercises over an individual. It may present many varied characteristics, from a simple moral influence with no perceptible exterior signs, to a complete organic and mental perturbation.... In the same manner that sicknesses are the result of our physical imperfections, which make the body accessible to pernicious exterior influences, obsession is always the result of moral imperfections, which allow the access of a bad Spirit.... It is very important to free the person from these negative vaporous fluids." Furthermore, in the book "Disobsession" [111], "We reiterate that Spiritism is Restored Christianity and that the leading Pioneer in disobsession, through enlightening unhappy spirits and curing the afflicted of all ailments was indeed Jesus himself."

Scientific Evidence. Despite the number of articles on spirit possession, few studies have evaluated disobsession (spirit release therapy) and its relationship with health outcomes. Consequently, no studies were selected for our final analysis. 
However, one study compared reported expectations and outcomes of mental health center patients and patients of Spiritist healers [112]. According to the author, the Spiritists' patients reported significantly higher expectations, especially for complaints regarding mood and feelings. Both patient groups had a similar duration and severity of symptoms. The outcome ratings of Spiritists' patients were significantly better than those of therapists', but this difference could be accounted for by the higher expectations of the Spiritists' patients. Nevertheless, this study had several limitations: noncontrolled and nonrandomized research, inadequate statistical analysis, comparison between conventional treatment versus alternative treatment yet not for the two associated. Unfortunately, no conclusions could be drawn from this study.

Another study [113], not indexed on the Medline database and thus not included in our final analysis, was conducted in Brazil. The authors evaluated 40 patients with mental disabilities (20 submitted to disobsession sessions and 20 controls, with usual care in both). The Interactive Observation Scale for Psychiatric Inpatients (IOSPI) was employed to evaluate outcomes. The comparison of the control group with the experimental group verified a difference in variation between the groups $(P=.045)$, demonstrating possible benefits of this intervention.

Some studies have assessed psychiatric disorders in mediums. An interesting paper [114] studied the similarities and differences between Brazilian Spiritist mediums and North American dissociative identity disorder (DID) patients and found that, compared with DID patients, the mediums differed in having better social adjustment, lower prevalence of mental disorders, lower use of mental health services, no use of antipsychotics, and lower prevalence of histories of physical or sexual childhood abuse, sleepwalking, secondary features of DID, and symptoms of borderline personality. According to the authors, mediumship differed from DID in having better mental health and social adjustment, and a different clinical profile. Similarly, Kua et al. [115] analyzed 36 young men with possession-trance. At followup four to five years later, none of the 26 who could be contacted showed any evidence of mental illness.

Another study [116] evaluated 115 mediums selected from different Kardecist Spiritist centers in São Paulo, Brazil and found that mediums included in this study had a high socioeducational level, a low prevalence of mental disorders and were socially well adjusted. The mediumistic process was characterized by dissociative and psychotic experiences that were not related to mental disorders.

Study Limitations. Only one study assessed disobsession (spirit release therapy), based on a randomized, controlled and blinded trial. However, several methodological issues need to be addressed such as challenges in standardizing treatment, the many different religions that use these techniques, and the ideal frequency and duration of these sessions. Additionally, mediumship must be reliable (raising the questions: what is reliable mediumship scientifically and how can this be measured?), where the medium should be evaluated for psychiatric conditions such as schizophrenia.
Future Directions. We should highlight that these therapies are complementary and not substitutes for usual care. Thus, an intervention group can receive spirit release therapy plus usual care while the control group receives only usual care. Furthermore, many outcomes could be tested such as mental disorders, mortality, hospitalization, well being, and selfreported health.

Gaining a deeper understanding of spirit possession, how it works and how it can help patients, is necessary to further assess this hypothesis. At present, numerous questions remain unanswered in this field.

Conclusion. There is a lack of well-conducted controlled, double-blind studies concerning disobsession (spirit release therapy), precluding support or rejection of this hypothesis at the present time. Further studies are now needed in this field.

\section{Discussion}

This systematic review has some limitations that should be pointed out. First, it comprised an extensive review of a highly complex field, and thus some important keywords may have been omitted in the present analysis. Second, in spite of being the most known and one of the most important medical databases in the world, Medline may not hold all relevant studies in this field, leading to the omission of some studies in this paper. Third, the Newcastle-Ottawa and Jadad score are very reliable measures but have some limitations resulting in some sound studies being excluded.

We should also point up that most studies evaluated were observational and not RCT studies and these studies were not carried out in Brazil. Therefore, generalizability is limited, and replication is needed.

However, this paper indicates a new field of research not yet fully explored by medical science. It shows that science is indirectly demonstrating that some of these therapies are related with better health outcomes while other treatments have been overlooked or poorly assessed. Fresh studies in this field could help the discipline of Complementary and Alternative Medicine to investigate the relationship between body, mind, and soul/spirit. Furthermore, discussing and assessing new methodological approaches to conduct these studies are important in order to scientifically prove these associations or otherwise.

Spiritism is present in more than 31 countries outside Latin America (including Porto Rico, United States, Portugal), and these therapies are based on simple and noncostly procedures. According to Bragdon [13] in her article "Spiritist healing centers in Brazil," "There are millions of Spiritists who go about the work of reforma intima, channeling, healing, praying, and doing charity work-without commercialization, self-serving promotion, or flamboyant display. Their way of life may in fact be the essence of a healing life of the spirit: it is a way of life that allows the individual to become whole, more healthy, more knowledgeable, more giving, more connected to community and higher power, and consistently progressing on the path of spiritual evolution." 
According to Spiritism [117], "For Earthly man, health may mean perfect balance of material organs; on the spritual plane however, health is the perfect harmony of the soul, which often can only be achieved by the invaluable contribution of the transient ills and deficiencies of Earth.”

Although these therapies have been little studied and are poorly understood by modern day science, some initiatives such as the NUPES (Núcleo de Pesquisas em Espiritualidade e Saúde) by the Federal University of Juiz de Fora, Brazil, São Paulo, Brazilian and International Medical Spiritist Association, Brazil, PROSER (Programa de Saúde e Espiritualidade) from the University of São Paulo, Brazil and, João Evangelista Hospital, Brazil are trying to encourage further scientific research into spiritual healing protocols and to promote international congresses.

Moreira-Almeida and Neto [110] wrote, "The importance of Spiritist views in Brazil indicates the need for more academic research on this tradition." The present authors share this view. Now is the time to undertake a thorough investigation on spiritual treatments, regardless of religious affiliation or scientific dogmas.

"Unshakable faith is only that which can meet reason face to face in every human epoch"-Kardec.

\section{References}

[1] A. Pierucci, “"Bye bye, Brasil”: o declínio das religiões tradicionais no Censo 2000," Estudos Avançados, vol. 18, pp. 1728, 2004.

[2] P. C. C. Fernandes, "Origens do espiritismo no Brasil: diálogo, razão e resistência no início de uma experiência (1850-1914)," Sociedade e Estado, vol. 23, no. 3, pp. 785-812, 2008.

[3] A. Kardec, Spirits' Book, Kessinger Publishing, Kila, Mont, USA, 1998.

[4] B. Lewgoy, "A transnacionalização do espiritismo kardecista brasileiro: uma discussão inicial," Religião \& Sociedade, vol. 28, pp. 84-104, 2008.

[5] A. Kardec, Qu'est-ce que le Spiritisme, Dervy-Livres, Paris, France, 1859/1975.

[6] A. Kardec, Revista Espírita [Revue Spirite], IDE, Araras, Brazil, 1861.

[7] A. Kardec, Revista Espírita [Revue Spirite], IDE, Araras, Brazil, 1868.

[8] A. Kardec, Genesis: The Miracles and the Predictions According to Spiritism, Colby \& Rich, Boston, Mass, USA, 1868.

[9] A. Kardec, Genesis: The Miracles and the Predictions According to Spiritism, Colby \& Rich, Boston, Mass, USA, 2008.

[10] A. Moreira-Almeida, A. A. Silva De Almeida, and F. L. Neto, "History of 'Spiritist madness' in Brazil," History of Psychiatry, vol. 16, no. 1, p. 5, 2005.

[11] L. R. Oliveira, "Terapia Complementar Espírita. Folha Espírita," http://www.amebrasil.org.br/portal/?q=node/139.

[12] C. Vincent and A. Furnham, Complementary Medicine: A Research Perspective, John Wiley \& Sons, New York, NY, USA, 1997.

[13] E. Bragdon, "Spiritist healing centers in Brazil," Seminars in Integrative Medicine, vol. 3, no. 2, pp. 67-74, 2005.

[14] L. H. Powell, L. Shahabi, and C. E. Thoresen, "Religion and spirituality: linkages to physical health," American Psychologist, vol. 58, no. 1, pp. 36-52, 2003.
[15] G. Wells, B. Shea, and D. O'Connell, "The Newcastle-Ottawa scale (NOS) for assessing the quality of nonrandomized studies in meta-analyses," Ottawa Health Research Institute, http://www.ohri.ca/programs/clinical_epidemiology/oxford .asp.

[16] S. S. Mahid, N. S. Jafri, B. C. Brangers, K. S. Minor, C. A. Hornung, and S. Galandiuk, "Meta-analysis of cholecystectomy in symptomatic patients with positive hepatobiliary iminodiacetic acid scan results without gallstones," Archives of Surgery, vol. 144, no. 2, pp. 180-187, 2009.

[17] S. Simon, Statistical Evidence in Medical Trials: What Do the Data Really Tell Us? Oxford University Press, New York, NY, USA, 2006.

[18] A. Ameling, "Prayer: an ancient healing practice becomes new again," Holistic Nursing Practice, vol. 14, no. 3, pp. 40$48,2000$.

[19] A. M. McCaffrey, D. M. Eisenberg, A. T. R. Legedza, R. B. Davis, and R. S. Phillips, "Prayer for health concerns: results of a national survey on prevalence and patterns of use," Archives of Internal Medicine, vol. 164, no. 8, pp. 858-862, 2004.

[20] A. Kardec, The Gospel According to Spiritism, International Spiritist Council, London, UK, 1864.

[21] A. Kardec, The Gospel According to Spiritism, International Spiritist Council, London, UK, 2004.

[22] F. C. Xavier, Nos Domínios da Mediunidade, FEB, Rio de Janeiro, Brazil, 10th edition, 1955.

[23] F. C. Xavier, Nos Domínios da Mediunidade, FEB, Rio de Janeiro, Brazil, 10th edition, 1993.

[24] K. S. Masters, G. I. Spielmans, and J. T. Goodson, "Are there demonstrable effects of distant intercessory prayer? A metaanalytic review," Annals of Behavioral Medicine, vol. 32, no. 1, pp. 21-26, 2006.

[25] A. L. Ai, P. Wink, T. N. Tice, S. F. Bolling, and M. Shearer, "Prayer and reverence in naturalistic, aesthetic, and sociomoral contexts predicted fewer complications following coronary artery bypass," Journal of Behavioral Medicine, vol. 32, no. 6, pp. 570-581, 2009.

[26] A. L. Ai, C. Peterson, S. F. Bolling, and H. Koenig, "Private prayer and optimism in middle-aged and older patients awaiting cardiac surgery," Gerontologist, vol. 42, no. 1, pp. 7081, 2002.

[27] A. L. Ai, C. Peterson, T. N. Tice, . Bu Huang, W. Rodgers, and S. F. Bolling, "The influence of prayer coping on mental health among cardiac surgery patients: the role of optimism and acute distress," Journal of Health Psychology, vol. 12, no. 4, pp. 580-596, 2007.

[28] A. L. Ai, R. E. Dunkle, C. Peterson, and S. F. Bolling, "The role of private prayer in psychological recovery among midlife and aged patients following cardiac surgery," Gerontologist, vol. 38, no. 5, pp. 591-601, 1998.

[29] A. L. Ai, C. S. Corley, C. Peterson, BU. Huang, and T. N. Tice, "Private prayer and quality of life in cardiac patients: pathways of cognitive coping and social support," Social Work in Health Care, vol. 48, no. 4, pp. 471-494, 2009.

[30] A. W. Braam, D. J. H. Deeg, J. L. Poppelaars, A. T. F. Beekman, and W. Van Tilburg, "Prayer and depressive symptoms in a period of secularization: patterns among older adults in the Netherlands," American Journal of Geriatric Psychiatry, vol. 15, no. 4, pp. 273-281, 2007.

[31] B. Rubik, "The biofield hypothesis: its biophysical basis and role in medicine," Journal of Alternative and Complementary Medicine, vol. 8, no. 6, pp. 703-717, 2002. 
[32] D. M. Eisenberg, R. B. Davis, S. L. Ettner et al., "Trends in alternative medicine use in the United States, 19901997: results of a follow-up national survey," Journal of the American Medical Association, vol. 280, no. 18, pp. 15691575, 1998.

[33] F. C. Xavier, O Consolador, FEB, Rio de Janeiro, Brazil, $1941 / 1999$.

[34] A. Kardec, A Gênese: Os Milagres e as Previsòes Segundo o Espiritismo, FEB, Rio de Janeiro, Brazil, 52nd edition, 1868.

[35] A. Kardec, A Gênese: Os Milagres e as Previsòes Segundo o Espiritismo, FEB, Rio de Janeiro, Brazil, 52nd edition, 2008.

[36] D. L. Woods, C. Beck, and K. Sinha, "The effect of therapeutic touch on behavioral symptoms and cortisol in persons with dementia," Forschende Komplementarmedizin, vol. 16, no. 3, pp. 181-189, 2009.

[37] P. Hawranik, P. Johnston, and J. Deatrich, "Therapeutic touch and agitation in individuals with Alzheimer's disease," Western Journal of Nursing Research, vol. 30, no. 4, pp. 417434, 2008.

[38] D. L. Woods, R. F. Craven, and J. Whitney, "The effect of therapeutic touch on behavioral symptoms of persons with dementia," Alternative Therapies in Health and Medicine, vol. 11, no. 1, pp. 66-74, 2005.

[39] N. Aghabati, E. Mohammadi, and Z. Pour Esmaiel, "The effect of therapeutic touch on pain and fatigue of cancer patients undergoing chemotherapy," Evidence-Based Complementary and Alternative Medicine, vol. 7, no. 3, pp. 375-381, 2010.

[40] A. Gordon, J. H. Merenstein, F. D'Amico, and D. Hudgens, "The effects of therapeutic touch on patients with osteoarthritis of the knee," Journal of Family Practice, vol. 47, no. 4, pp. 271-277, 1998.

[41] J. G. Turner, A. J. Clark, D. K. Gauthier, and M. Williams, "The effect of therapeutic touch on pain and anxiety in burn patients," Journal of Advanced Nursing, vol. 28, no. 1, pp. 1020, 1998.

[42] E. Keller and V. M. Bzdek, "Effects of therapeutic touch on tension headache pain," Nursing Research, vol. 35, no. 2, pp. 101-106, 1986.

[43] L. S. Frank, J. L. Frank, D. March, G. Makari-Judson, R. B. Barham, and W. C. Mertens, "Does therapeutic touch ease the discomfort or distress of patients undergoing stereotactic core breast biopsy? A randomized clinical trial," Pain Medicine, vol. 8, no. 5, pp. 419-424, 2007.

[44] R. P. Blankfield, C. Sulzmann, L. G. Fradley, A. A. Tapolyai, and S. J. Zyzanski, "Therapeutic touch in the treatment of carpal tunnel syndrome," Journal of the American Board of Family Practice, vol. 14, no. 5, pp. 335-342, 2001.

[45] T. C. Meehan, "Therapeutic touch and postoperative pain: a Rogerian research study," Nursing Science Quarterly, vol. 6, no. 2, pp. 69-78, 1993.

[46] V. M. Gomes, M. J. Silva, and E. A. Araújo, "Gradual effects of therapeutic touch in reducing anxiety in university students," Revista Brasileira de Enfermagem, vol. 61, no. 6, pp. 841-846, 2008.

[47] G. A. Gronowicz, A. Jhaveri, L. W. Clarke, M. S. Aronow, and T. H. Smith, "Therapeutic touch stimulates the proliferation of human cells in culture," Journal of Alternative and Complementary Medicine, vol. 14, no. 3, pp. 233-239, 2008.

[48] A. Jhaveri, S. J. Walsh, Y. Wang, M. McCarthy, and G. Gronowicz, "Therapeutic touch affects DNA synthesis and mineralization of human osteoblasts in culture," Journal of Orthopaedic Research, vol. 26, no. 11, pp. 1541-1546, 2008.
[49] Z. Movaffaghi, M. Hasanpoor, M. Farsi, P. Hooshmand, and F. Abrishami, "Effects of therapeutic touch on blood hemoglobin and hematocrit level," Journal of Holistic Nursing, vol. 24, no. 1, pp. 41-48, 2006.

[50] D. Krieger, Accepting Your Power to Heal: The Personal Practice of Therapeutic Touch, Bear \& Co, Dublin, Ireland, 1993.

[51] G. Pohl, H. Seemann, N. Zojer et al., "'Laying on of hands" improves well-being in patients with advanced cancer," Supportive Care in Cancer, vol. 15, no. 2, pp. 143-151, 2007.

[52] D. Radin, G. Hayssen, M. Emoto, and T. Kizu, "Doubleblind test of the effects of distant intention on water crystal formation," Explore: The Journal of Science and Healing, vol. 2, no. 5, pp. 408-411, 2006.

[53] M. Emoto, "Healing with Water," Journal of Alternative and Complementary Medicine, vol. 10, no. 1, pp. 19-21, 2004.

[54] F. C. Xavier, Segue-Me, O Clarim, Brazil, 7th edition, 1994.

[55] K. E. Johnson, J. J. Sanders, R. G. Gellin, and Y. Y. Palesch, "The effectiveness of a magnetized water oral irrigator (Hydro Floss ${ }^{\circledR}$ ) on plaque, calculus and gingival health," Journal of Clinical Periodontology, vol. 25, no. 4, pp. 316-321, 1998.

[56] D. L. Watt, C. Rosenfelder, and C. D. Sutton, "The effect of oral irrigation with a magnetic water treatment device on plaque and calculus," Journal of Clinical Periodontology, vol. 20, no. 5, pp. 314-317, 1993.

[57] R. Savieto, M. Silva, D. Pozzi, and P. Ferreira Neto, “ Ação da água energizada com o toque terapêutico na cicatrização de lesões na pele de camundongos; Scarring effects of water energized with therapeutic touch on mice skin," Revista Enfermagem UERJ, vol. 15, no. 3, pp. 423-429, 2007.

[58] R. Savieto and M. Silva, "Efeitos do toque terapêutico na cicatrização de lesões da pele de cobaias," Acta Paulista de Enfermagem, vol. 17, pp. 377-382, 2004.

[59] R. M. Savieto and M. J. da Silva, "Therapeutic touch for the healing of skin injuries in guinea pigsToque terapéutico na cicatrização de lesões da pele de cobaias," Revista Brasileira de Enfermagem, vol. 57, no. 3, pp. 340-343, 2004.

[60] M. A. Yi-Long, R. Hui, R. Shu, Z. Er-Kang, H. Gang, and $\mathrm{Z}$. Yao-Wu, "A study of the effect of magnetized water on enzyme activities by potentiometric enzyme electrode method," Journal of Tongji Medical University, vol. 12, no. 4, pp. 193-196, 1992.

[61] I. U. Merkulova and M. L. Mikhel'son, "The therapeutic action of magnetized water on the quality of health at a sanatorium," Voprosy Kurortologii, Fizioterapii, I Lechebnoi Fizicheskoi Kultury, no. 2, pp. 37-39, 1994.

[62] M. L. Mikhel'son and I. U. Merkulova, "The biological and bactericidal actions of magnetized water," Voprosy Kurortologii, Fizioterapii, I Lechebnoi Fizicheskoi Kultury, no. 2, pp. 35-37, 1994.

[63] Y. S. Zhang and H. W. Wu, "Effect of magnetic water on urinary calculi-an experimental and clinical studyDer Einfluss von magnetischem Wasser auf Harnsteine-eine experimentelle und klinische Studie," Zeitschrift fur Urologie und Nephrologie, vol. 80, no. 9, pp. 517-523, 1987.

[64] J. G. Zhang, "Preventing bacillary dysentery with magnetized drinking water," Zhonghua Liu Xing Bing Xue Za Zhi, vol. 6, no. 4, pp. 203-205, 1985.

[65] S. G. Post, "Altruism, happiness, and health: it's good to be good," International Journal of Behavioral Medicine, vol. 12, no. 2, pp. 66-77, 2005.

[66] A. Luks, "Helper's high: volunteering makes people feel good, physically and emotionally," Psychology Today, vol. 22, no. 10, pp. 34-42, 1988. 
[67] A. Kardec, O Evangelho Segundo o Espiritismo [The Gospel According to Spiritism], Instituto de Difusão Espirita, São Paulo, Brazil, 1864.

[68] A. H. S. Harris and C. E. Thoresen, "Volunteering is associated with delayed mortality in older people: analysis of the longitudinal study of aging," Journal of Health Psychology, vol. 10, no. 6, pp. 739-752, 2005.

[69] M. A. Musick, A. R. Herzog, and J. S. House, "Volunteering and mortality among older adults: findings from a national sample," Journals of Gerontology-Series B, vol. 54, no. 3, pp. S173-S180, 1999.

[70] L. Ayalon, "Volunteering as a predictor of all-cause mortality: what aspects of volunteering really matter?" International Psychogeriatrics, vol. 20, no. 5, pp. 1000-1013, 2008.

[71] K. Pillemer, T. E. Fuller-Rowell, M. C. Reid, and N. M. Wells, "Environmental volunteering and health outcomes over a 20year period," Gerontologist, vol. 50, no. 5, pp. 594-602, 2010.

[72] N. Krause, "Church-based volunteering, providing informal support at church, and self-rated health in late life," Journal of Aging and Health, vol. 21, no. 1, pp. 63-84, 2009.

[73] J. A. Piliavin and E. Siegl, "Health benefits of volunteering in the Wisconsin longitudinal study," Journal of Health and Social Behavior, vol. 48, no. 4, pp. 450-464, 2007.

[74] N. Morrow-Howell, J. Hinterlong, P. A. Rozario, and F. Tang, "Effects of volunteering on the well-being of older adults," Journals of Gerontology-Series B, vol. 58, no. 3, pp. S137S145, 2003.

[75] M. Van Willigen, "Differential benefits of volunteering across the life course," Journals of Gerontology-Series B, vol. 55, no. 5, pp. S308-S318, 2000.

[76] M. A. Musick and J. Wilson, "Volunteering and depression: the role of psychological and social resources in different age groups," Social Science and Medicine, vol. 56, no. 2, pp. 259269, 2003.

[77] J. Kim and M. Pai, "Volunteering and trajectories of depression," Journal of Aging and Health, vol. 22, no. 1, pp. 84-105, 2010.

[78] J. E. Williams, C. C. Paton, I. C. Siegler, M. L. Eigenbrodt, F. J. Nieto, and H. A. Tyroler, "Anger proneness predicts coronary heart disease risk: prospective analysis from the atherosclerosis risk in communities (ARIC) study," Circulation, vol. 101, no. 17, pp. 2034-2039, 2000.

[79] F. Luskin, Forgive for Good: A Proven Prescription for Health and Happiness, Harper, San Francisco, Calif, USA, 2002.

[80] M. Dillon and P. Wink, In the Course of a Lifetime: Tracing Religious Belief, Practice, and Change, University of California Press, Berkeley, Calif, USA, 2007.

[81] FEB, "What's Spiritist Education?" March 2009, http://www .spiritisteducation.net/Spiritist_Education/Home_files/WhatisSpiritistEducation.pdf.

[82] J. Xu and R. E. Roberts, "The power of positive emotions: it's a matter of life or death-subjective well-being and longevity over 28 years in a general population," Health Psychology, vol. 29, no. 1, pp. 9-19, 2010.

[83] J. T. Moskowitz, E. S. Epel, and M. Acree, "Positive affect uniquely predicts lower risk of mortality in people with diabetes," Health Psychology, vol. 27, no. 1, supplement, pp. S73-S82, 2008.

[84] J. T. Moskowitz, "Positive affect predicts lower risk of AIDS mortality," Psychosomatic Medicine, vol. 65, no. 4, pp. 620 626, 2003.
[85] D. D. Danner, D. A. Snowdon, and W. V. Friesen, "Positive emotions in early life and longevity: findings from the nun study," Journal of Personality and Social Psychology, vol. 80, no. 5, pp. 804-813, 2001.

[86] K. W. Davidson, E. Mostofsky, and W. Whang, "Don't worry, be happy: positive affect and reduced 10-year incident coronary heart disease: the Canadian nova scotia health survey," European Heart Journal, vol. 31, no. 9, pp. 10651070, 2010.

[87] J. Denollet, S. S. Pedersen, J. Daemen, P. De Jaegere, P. W. Serruys, and R. T. Van Domburg, "Reduced positive affect (anhedonia) predicts major clinical events following implantation of coronary-artery stents," Journal of Internal Medicine, vol. 263, no. 2, pp. 203-211, 2008.

[88] E. Park-Lee, L. Fredman, M. Hochberg, and K. Faulkner, "Positive affect and incidence of frailty in elderly women caregivers and noncaregivers: results of caregiver-study of osteoporotic fractures," Journal of the American Geriatrics Society, vol. 57, no. 4, pp. 627-633, 2009.

[89] G. V. Ostir, K. J. Ottenbacher, and K. S. Markides, “Onset of frailty in older adults and the protective role of positive affect," Psychology and Aging, vol. 19, no. 3, pp. 402-408, 2004.

[90] M. N. Fisher, S. Al Snih, G. V. Ostir, and J. S. Goodwin, "Positive Affect and Disability among Older Mexican Americans with Arthritis," Arthritis Care and Research, vol. 51, no. 1, pp. 34-39, 2004.

[91] L. Fredman, W. G. Hawkes, S. Black, R. M. Bertrand, and J. Magaziner, "Elderly patients with hip fracture with positive affect have better functional recovery over 2 years," Journal of the American Geriatrics Society, vol. 54, no. 7, pp. 1074-1081, 2006.

[92] H. Versteeg, S. S. Pedersen, R. A. M. Erdman, J. W. I. Van Nierop, P. De Jaegere, and R. T. Van Domburg, "Negative and positive affect are independently associated with patientreported health status following percutaneous coronary intervention," Quality of Life Research, vol. 18, no. 8, pp. 953960, 2009.

[93] A. E. Skodol, D. S. Bender, M. E. Pagano et al., "Positive childhood experiences: resilience and recovery from personality disorder in early adulthood," Journal of Clinical Psychiatry, vol. 68, no. 7, pp. 1102-1108, 2007.

[94] K. Wattanakit, J. E. Williams, P. J. Schreiner, A. T. Hirsch, and A. R. Folsom, "Association of anger proneness, depression and low social support with peripheral arterial disease: the Atherosclerosis Risk in Communities Study," Vascular Medicine, vol. 10, no. 3, pp. 199-206, 2005.

[95] J. P. Yi, P. P. Vitaliano, R. E. Smith, J. C. Yi, and K. Weinger, "The role of resilience on psychological adjustment and physical health in patients with diabetes," British Journal of Health Psychology, vol. 13, no. 2, pp. 311-325, 2008.

[96] A. Walter-Ginzburg, D. Shmotkin, T. Blumstein, and A. Shorek, "A gender-based dynamic multidimensional longitudinal analysis of resilience and mortality in the old-old in Israel: the cross-sectional and longitudinal aging study (CALAS)," Social Science and Medicine, vol. 60, no. 8, pp. 1705-1715, 2005.

[97] S. Cohen, C. M. Alper, W. J. Doyle, J. J. Treanor, and R. B. Turner, "Positive emotional style predicts resistance to illness after experimental exposure to rhinovirus or influenza A virus," Psychosomatic Medicine, vol. 68, no. 6, pp. 809-815, 2006. 
[98] B. H. Brummett, S. H. Boyle, C. M. Kuhn, I. C. Siegler, and R. B. Williams, "Positive affect is associated with cardiovascular reactivity, norepinephrine level, and morning rise in salivary cortisol," Psychophysiology, vol. 46, no. 4, pp. 861-869, 2009.

[99] K. Buchanan and A. Bardi, "Acts of kindness and acts of novelty affect life satisfaction," Journal of Social Psychology, vol. 150, no. 3, pp. 235-237, 2010.

[100] K. Otake, S. Shimai, J. Tanaka-Matsumi, K. Otsui, and B. L. Fredrickson, "Happy people become happier through kindness: a counting kindnesses intervention," Journal of Happiness Studies, vol. 7, no. 3, pp. 361-375, 2006.

[101] C. A. Hutcherson, E. M. Seppala, and J. J. Gross, "Lovingkindness meditation increases social connectedness," Emotion, vol. 8, no. 5, pp. 720-724, 2008.

[102] J. W. Carson, F. J. Keefe, T. R. Lynch et al., "Loving-kindness meditation for chronic low back pain: results from a pilot trial," Journal of Holistic Nursing, vol. 23, no. 3, pp. 287-304, 2005.

[103] M. Poulin and R. Cohen Silver, "World benevolence beliefs and well-being across the life span," Psychology and Aging, vol. 23, no. 1, pp. 13-23, 2008.

[104] A. Martínez-Taboas, "A case of spirit possession and glossolalia," Culture, Medicine and Psychiatry, vol. 23, no. 3, pp. 333-348, 1999.

[105] D. Somasundaram, T. Thivakaran, and D. Bhugra, "Possession states in northern Sri Lanka," Psychopathology, vol. 41, no. 4, pp. 245-253, 2008.

[106] S. Pfeifer, "Demonic attributions in nondelusional disorders," Psychopathology, vol. 32, no. 5, pp. 252-259, 1999.

[107] A. Powell, "The Contribution of Spirit Release Therapy to Mental Health. Royal College of Psychiatrists," January 2011, http://www.rcpsych.ac.uk/pdf/Andrew\%20Powell\%20The $\% 20$ Contribution $\% 20$ of $\% 20$ Spirit $\% 20$ Release $\% 20$ Therapy \%20to\%20Mental\%20Health\%20.pdf.

[108] R. Spitzer, Dsm-IV Casebook: A Learning Companion to the Diagnostic and Statistical Manual of Mental Disorders, American Psychiatric Publishing, Arlington, Va, USA, 1994.

[109] WHO, The ICD-10 Classification of Mental and Behavioural Disorders : Clinical Descriptions and Diagnostic Guidelines, World Health Organization, Geneva, Switzerland, 1992.

[110] A. Moreira-Almeida and F. L. Neto, "Spiritist views of mental disorders in Brazil," Transcultural Psychiatry, vol. 42, no. 4, pp. 570-595, 2005.

[111] F. C. Xavier and W. Vieira, "Desobsessão: Federação Espírita Brasileira," 1964, http://www.autoresespiritasclassicos.com/ Autores \%20Espiritas\%20Classicos\%20\%20Diversos/Chico \%20Xavier/Chico\%20Xavier/3/DESOBSESSAO/(Chico\%20 Xavier\%20-\%20Waldo\%20Vieira\%20-\%20Andr\%C3\%A9 \%20Luiz\%20-\%20Desobsess\%C3\%A3o.pdf.

[112] J. D. Koss, "Expectations and outcomes for patients given mental health care or spiritist healing in Puerto Rico," American Journal of Psychiatry, vol. 144, no. 1, pp. 56-61, 1987.

[113] F. C. Leão and F. L. Neto, "Spiritual practices in an institution for mental disabilitiesUso de práticas espirituais em instituição para portadores de deficiência mental," Revista de Psiquiatria Clinica, vol. 34, supplement 1, pp. 54-59, 2007.

[114] A. Moreira-Almeida, F. L. Neto, and E. Cardeña, "Comparison of Brazilian spiritist mediumship and dissociative identity disorder," Journal of Nervous and Mental Disease, vol. 196, no. 5, pp. 420-424, 2008.
[115] E. Kua, L. Sim, and K. Chee, "A cross-cultural study of the possession-trance in Singapore," Australian and New Zealand Journal of Psychiatry, vol. 20, no. 3, pp. 361-364, 1986.

[116] A. Moreira-Almeida, F. Lotufo Neto, and B. Greyson, "Dissociative and psychotic experiences in Brazilian spiritist mediums," Psychotherapy and Psychosomatics, vol. 76, no. 1, pp. 57-58, 2006.

[117] F. C. Xavier, O Consolador, pelo Espírito Emmanuel, Federação Espírita Brasileira, Rio de Janeiro, Brazil, 23rd edition, 2001. 


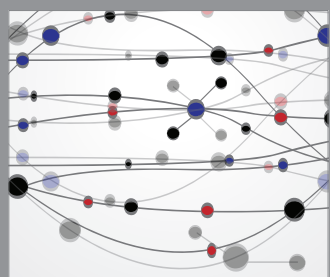

The Scientific World Journal
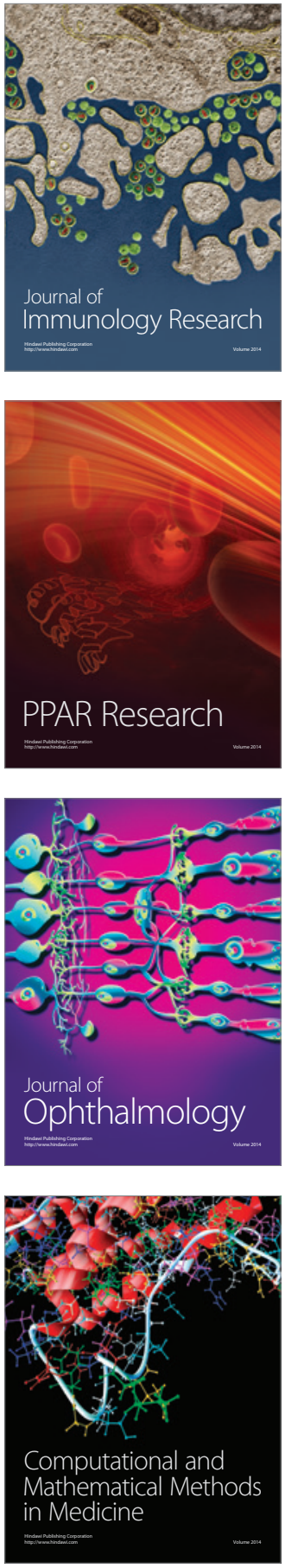

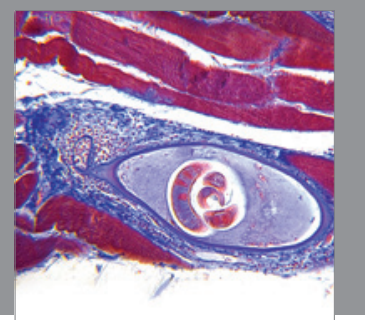

Gastroenterology

Research and Practice
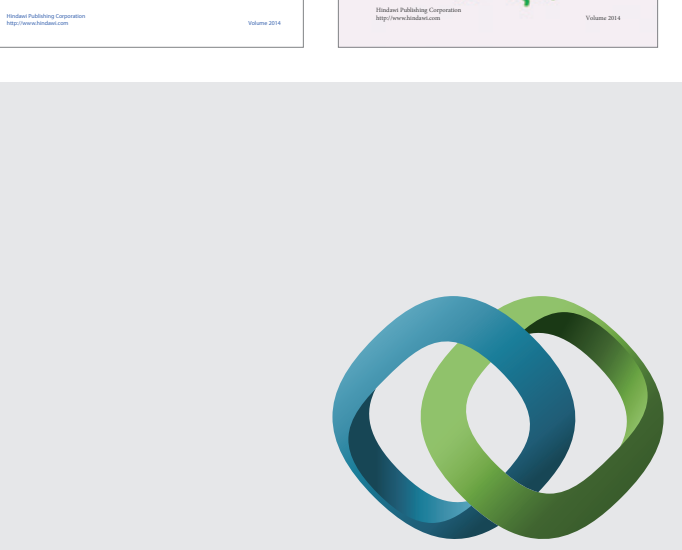

\section{Hindawi}

Submit your manuscripts at

http://www.hindawi.com
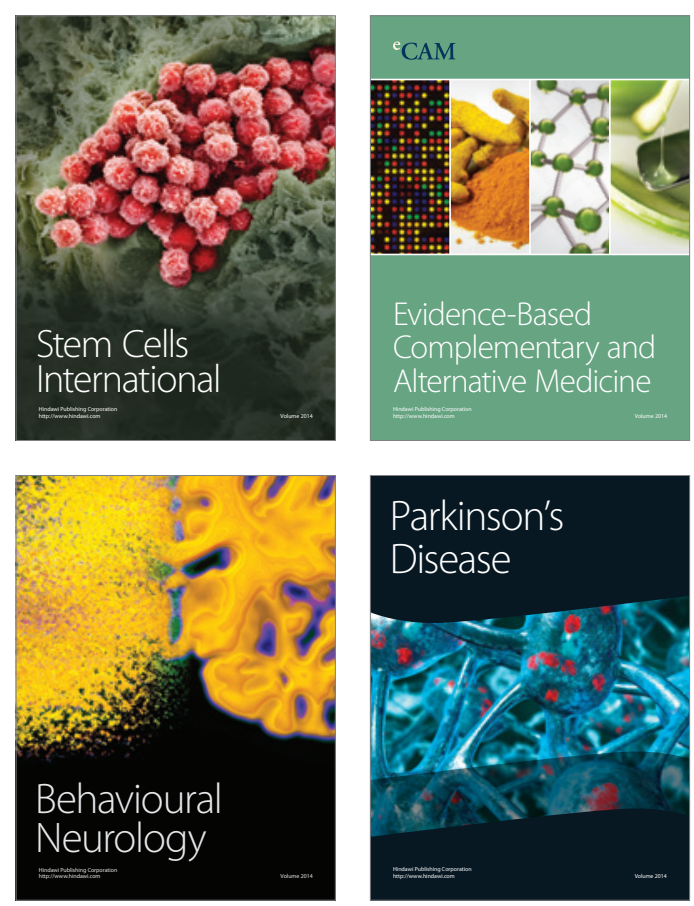

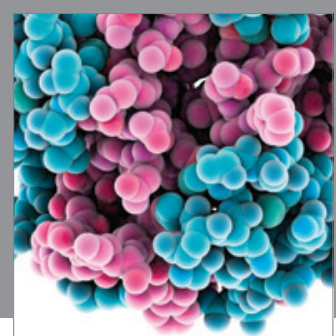

Journal of
Diabetes Research

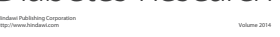

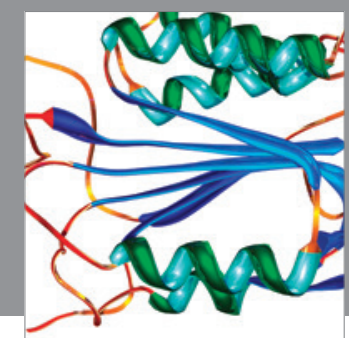

Disease Markers
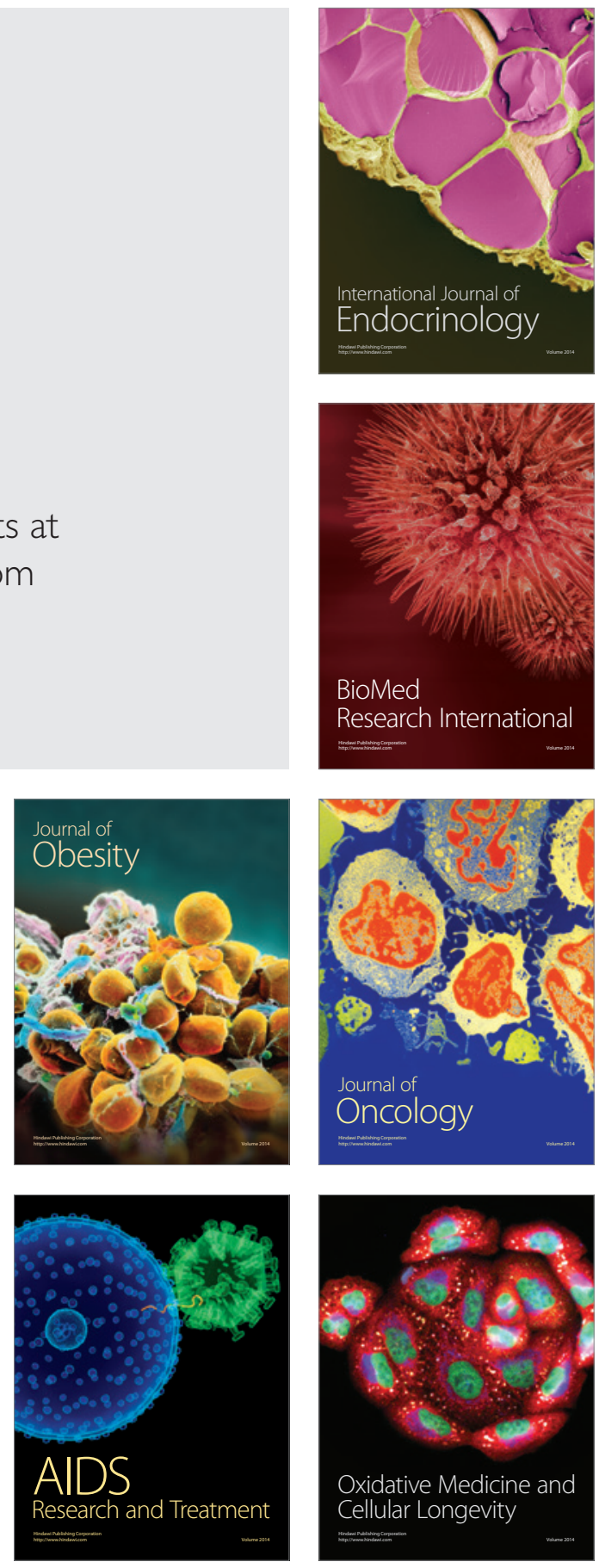